Review

\title{
Post-Immune Antibodies in HIV-1 Infection in the Context of Vaccine Development: A Variety of Biological Functions and Catalytic Activities
}

\author{
Anna Timofeeva ${ }^{1, *(\mathbb{D})}$, Sergey Sedykh ${ }^{1,2}$ (D) and Georgy Nevinsky ${ }^{1,2}$ (D) \\ 1 SB RAS Institute of Chemical Biology and Fundamental Medicine, 630090 Novosibirsk, Russia; \\ sedyh@niboch.nsc.ru (S.S.); nevinsky@niboch.nsc.ru (G.N.) \\ 2 Faculty of Natural Sciences, Novosibirsk State University, 630090 Novosibirsk, Russia \\ * Correspondence: anna.m.timofeeva@gmail.com; Tel.: +7-91-32-027-154
}

check for updates

Citation: Timofeeva, A.; Sedykh, S.; Nevinsky, G. Post-Immune Antibodies in HIV-1 Infection in the Context of Vaccine Development: A Variety of Biological Functions and Catalytic Activities. Vaccines 2022, 10, 384. https://doi.org/10.3390/ vaccines 10030384

Academic Editors: Christina B. Karsten and Rob J. Center

Received: 10 January 2022 Accepted: 28 February 2022 Published: 2 March 2022

Publisher's Note: MDPI stays neutral with regard to jurisdictional claims in published maps and institutional affiliations.

Copyright: (C) 2022 by the authors. Licensee MDPI, Basel, Switzerland. This article is an open access article distributed under the terms and conditions of the Creative Commons Attribution (CC BY) license (https:// creativecommons.org/licenses/by/ $4.0 /)$.

\begin{abstract}
Unlike many other viruses, HIV-1 is highly variable. The structure of the viral envelope changes as the infection progresses and is one of the biggest obstacles in developing an HIV-1 vaccine. HIV-1 infection can cause the production of various natural autoantibodies, including catalytic antibodies hydrolyzing DNA, myelin basic protein, histones, HIV-integrase, HIV-reverse transcriptase, $\beta$-casein, serum albumin, and some other natural substrates. Currently, there are various directions for the development of HIV-1 vaccines: stimulation of the immune response on the mucous membranes; induction of cytotoxic T cells, which lyse infected cells and hold back HIV-infection; immunization with recombinant Env proteins or vectors encoding Env; mRNA-based vaccines and some others. However, despite many attempts to develop an HIV-1 vaccine, none have been successful. Here we review the entire spectrum of antibodies found in HIV-infected patients, including neutralizing antibodies specific to various viral epitopes, as well as antibodies formed against various autoantigens, catalytic antibodies against autoantigens, and some viral proteins. We consider various promising targets for developing a vaccine that will not produce unwanted antibodies in vaccinated patients. In addition, we review common problems in the development of a vaccine against HIV-1.
\end{abstract}

Keywords: HIV; antibodies; IgG; neutralizing antibodies; viral envelope; vaccine; HIV-1 vaccine; catalytic antibodies

\section{Introduction}

Since the first clinical detection of AIDS (acquired immunodeficiency syndrome) and the subsequent isolation of HIV (human immunodeficiency virus) in the early 1980s, the HIV epidemic continues to be one of the major health threats in the world, despite four decades of intensive research [1].

A high level of genetic variability in HIV-1 is one of the biggest obstacles in developing a safe and effective vaccine. Unlike many other viruses, HIV-1 is highly variable, with many subtypes and recombinant forms [2,3]. Low fidelity of HIV-1 reverse transcriptase leads to the rapid generation of mutants carrying base substitutions, insertions, and deletions. Combined with the addition and loss of glycosylation sites, this results in tremendous viral diversity [4-6]. A key source of genetic diversity is the viral gene env, which encodes envelope glycoprotein (Env), gp120, and gp41. As is known, gp120 and gp41 subunits on the surface of the virion are trimerized, form spikes, and together are involved in penetration into the target cell. Env has a complex conformation and undergoes significant rearrangements when binding to CD4 and coreceptors [7-9]. Glycans make up half the mass of the HIV-1 envelope glycoprotein, forming a topographic landscape that alters the availability of antibody ( $\mathrm{Ab})$ binding to the immunogen [10]. 
Env is also a major target for neutralizing antibodies (nAbs) [11,12]. The inability of the adaptive immune system to prevent and control infection is explained by the structural variability of the HIV-1 envelope. Protein gp120 consists of five relatively constant (C) regions and five highly variable $(\mathrm{V})$ regions. Most adaptive responses target V-domain epitopes that mutate rapidly [13]. Cytotoxic T-lymphocytes and nAbs provide only temporary protection [14,15].

Progression of HIV-1 infection to AIDS occurs over 1 year to more than 2 decades [16]. Some HIV-infected patients develop Abs that can neutralize a wide range of HIV-1 strains [17-19]. HIV-1 has mechanisms preventing the production of broadly neutralizing antibodies (bNAbs) (Figure 1), including intense glycosylation of Env glycoproteins, instability of these glycoproteins, and conformational masking of receptor binding sites [20-22]. However, the mechanism behind the production of these bNAbs, and why it only occurs in some patients is not clear.

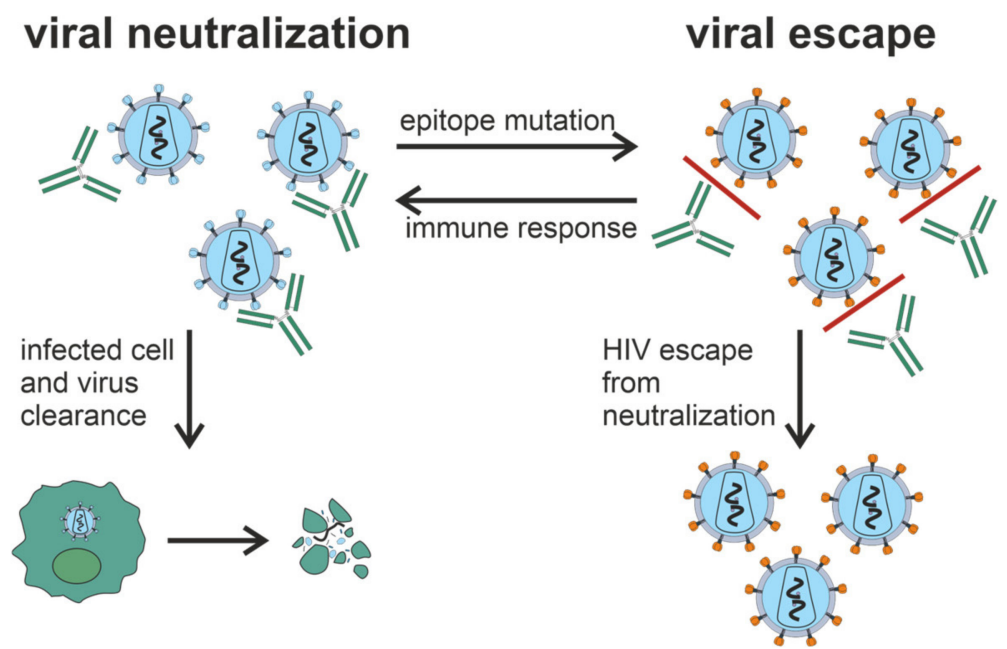

Figure 1. Generation of bNAbs, which neutralize the virus through binding to viral spikes and blocking the entry of the virus into sensitive cells such as $\mathrm{CD} 4^{+} \mathrm{T}$ cells, is related to the evasion of virus from the immune response due to the low precision of HIV-1 reverse transcriptase and rapid generation of viral mutants. Glycan shield, immunodominant variable loops, and conformational masking of key viral epitopes protect Env from Ab-response.

Despite the enormous diversity of HIV-1, there are described a few bNAbs such as b12 [23,24], 2G12 [24,25], 4E10 [26], 2F5 [24,27], VRC01 [28], PG9/PG16, 447-52D [29]. As shown in [30-32], b12 Ab isolated from the phage display library can neutralize about $40 \%$ of known HIV-1 strains. Another monoclonal antibody (mAb) HJ16, also neutralizes about $40 \%$ of viral isolates [33]. Most of the structures of such monoclonal bNAbs are resolved in complexes with Env $[8,34]$. These structures can be used to develop immunogens capable of eliciting bNAbs. Under the International AIDS Vaccine Initiative Neutralizing Antibody Consortium, a global program was established to identify HIV-infected individuals with broad and potent $\mathrm{nAb}$ activity as a potential source of new monoclonal bNAbs [20].

Although the detection of circulating autoantibodies (autoAbs) to self-antigens in patients infected by HIV-1 or other viruses does not necessarily reflect the presence of an autoimmune disease, such autoAbs can certainly complicate viral infections. These responses may vary due to the infection of autologous cells by the virus and their consequent targeting by pre-existing and/or induced autoAbs against the virus. Several natural autoAbs were described in HIV-infection [35]: Abs against small nuclear ribonucleoproteins (snRNP) [36], Abs to anticardiolipin (aCL) and antiglycoprotein 1 (aß2GP1), anti-DNA, and antinuclear Abs [37,38]. Common to some viral diseases and autoimmune pathologies, catalytic Abs (Abzymes) hydrolyzing DNA [39] and a variety of proteins were described in HIV / AIDS patients: histones [40], myelin basic protein (MBP) [41], HIV integrase [42,43] 
and HIV reverse transcriptase [39], $\beta$-casein and serum albumin [39]. Such autoAbs may be beneficial for patients, as they expel autologous cells expressing viral antigens from the body. Moreover, one cannot exclude that HIV-infected patients produce natural Abs that recognize both microbial and autologous antigens.

Several vaccines in preclinical tests consisted of single coat proteins or in combination with other HIV-1 proteins and multiepitope synthetic peptides and polypeptides expressed by noninfectious vectors. Numerous HIV-1 vaccine candidates are directed to the induction of $\mathrm{nAbs}$ and/or cytotoxic T cells [44]. Despite the induction of robust immune responses, the recombinant glycoprotein gp120 VaxGen [45] and Merck gag/pol/nef (STEP) adenoviral vaccine [46] did not reduce the risk of infection. RV144 vaccine, consisting of the full-length gp120 protein and canarypox vector, reduced the risk of disease by $31 \%$ [47]. Similar to the case of the ineffective response caused by candidate vaccines, the pos-immune response, which follows HIV-1 infection, usually does not control the further spread of the virus [48]. According to the literature reviewed, some HIV-1-infected individuals develop hypermutated $\mathrm{bNAbs}$ through a postimmune $\mathrm{Ab}$ response. Therefore, advanced editing of Env-targeting B cell receptors (BCRs) may gradually lead to the generation of bNAbs. It remains unknown whether B cells naturally expressing Env-targeting BCRs can act as templates for the generation of bNAbs. Chronic HIV-1 infection may lead to the extensive BCR somatic hypermutation and the generation of Env-directed bNAbs [49]; knockedin mice expressing unmutated common ancestors of BCR heavy and light chains show that HIV-1 Env immunization can boost the generation of bNAbs [50,51]. Recombinant Env immunogens may activate B cells that express the germline BCRs of bNAbs [52]. Vaccination of wild-type mice leads to affinity maturation of primary bNAb-engineered $B$ cells and the generation of bNAb-memory and plasma cells [53].

The induction of a protective $\mathrm{Ab}$ response remains a top priority in $\mathrm{HIV}-1$ vaccine development. Vaccines must be safe and not induce the development of Abs against autoantigens, which can exhibit autoreactive properties and trigger a cascade of various autoimmune reactions. It is known that immunization with one antigen can lead to polyreactive Abs, including those that bind to autoantigens.

In this review, we consider the whole spectrum of Abs described in HIV-infected patients, including nAbs (Section 2) specific to various viral epitopes, as well as Abs formed against various autoantigens (Section 3), including Abs with catalytic activity (Section 4) to these autoantigens and some viral proteins. In addition, we describe various approaches and difficulties on the way to the HIV-1 vaccine (Section 5) and the peculiarities of Abs production during COVID-19 in HIV-infected patients (Section 6).

\section{Neutralizing Antibodies in HIV-1 Infection}

Neutralizing Abs protect cells from a viral particle by binding it. These Abs surround the virus, after which the entire complex containing the virus is removed with the immune system. The induction of nAbs is a key goal of vaccination strategies [54,55].

During HIV-1 infection, almost all patients produce Abs to Env, but only a small fraction of these Abs can neutralize the virus [56,57]. Interestingly, nAbs against viral Env are produced within the first weeks of infection. Still, this early Ab response targets an autologous virus that circulates within each person and is ineffective against heterologous (unrelated) viruses [5].

Among the nAbs, a specific group of Abs neutralizing a wide spectrum of HIV-1 strains are distinguished. These broadly neutralizing antibodies (bNAbs) arise after several years of virus-antibody coevolution in infected patients [58-60]; bNAbs usually recognize conserved epitopes on the highly glycosylated envelope glycoprotein (Env) [61,62].

Several groups have shown that serum of 10 to $25 \%$ infected patients contains bNAbs [63-65]. Approximately 25\% of HIV-infected subjects who have been infected for at least 1 year, without clinical symptoms of AIDS, and not taking antiretroviral drug therapy, showed moderate to extensive $\mathrm{nAb}$ responses [64-66]. 
Structurally conserved regions of the Env are functionally important for viral attachment and entry into target cells. These are the CD4 binding site and the coreceptor binding site located at gp120 [63]. It was assumed that viral epitopes, conserved among most viral strains, would generate cross-reactive Abs. However, for not fully understood reasons, these conserved viral epitopes were either weakly immunogenic or produced Abs with limited neutralizing reactivity $[20,67]$.

Since the carbohydrates of Env glycoprotein may serve as a shield to evade the immune system, they can be used as targets for bNAb recognition [10]. Abs can bypass the glycan shield to access the surface of the viral protein. Rarely, bNAbs only recognize glycans; in contrast, glycan-dependent nAbs against HIV-1 targeting a combination of glycans and an underlying glycopeptide are not uncommon [68]. These glycopeptide-targeting Abs are often produced during natural infection [69].

Numerous works aim to study the specificity of Abs from HIV-infected patients and the relationship of these specificities with the breadth and efficiency of Ab-responses. At the same time, the study of epitope-specific nAbs is of particular interest since this data can be used in the development of vaccines [70]. The main challenge facing HIV-1 vaccine development is stimulating the bNAbs production; these issues are discussed in Section 5 of this review.

\subsection{General Characteristics of $n A b s$}

The first B cell response to HIV-1 infection appears within 8 days after detectable viremia [71]. After the next 5 days, circulating Abs against gp41 are detected, and after another 2 weeks, Abs against gp120 are detected, which primarily target the V3 loop. Autologous nAbs are developed over several months [70] and target variable HIV-1 regions by potent but particular molecules $[5,72,73]$. Over the years, Abs with neutralizing crossspecific potential developed in one third of chronically infected patients and targeted the more conserved regions of Env [63]. Heterologous nAbs appear in some patients 1 year after infection reach their peak after 4 years, with no increase after that [19]. High viral load is not a general predictor of $\mathrm{Ab}$ neutralization capacity since some patients with high viremia do not develop cross-neutralizing Abs [19,74].

The breadth of $\mathrm{Ab}$ neutralization is usually increased to the end of 2.5 years after infection [75]. In the long-term nonprogressor patients, all neutralizing Abs against gp120 were clonally associated with the antibody-diversifying process of somatic hypermutation [76]. $B$ cells producing bNAbs have been shown to undergo several rounds of affinity maturation in germinal centers to achieve cross-neutralizing activity $[77,78]$. BNAbs develop over time and are maintained by chronic antigen exposure. Broadly cross-reactive $\mathrm{nAb}$ responses occur over several years, which means that $\mathrm{Ab}$ maturation response is required to target specific conserved viral epitopes effectively. Sustained viral replication under the conditions Ab-response leads to the continuous evolution of the viral Env to avoid nAb. This antigenic evolution can gradually focus the $\mathrm{nAb}$ response on less immunogenic but more conserved regions of Env [63].

Dysregulation of the immune system in the later stages of HIV-1 infection leads to a decrease of new Ab-responses. The ability to generate new autologous responses is declined after 2-3 years of infection, regardless of disease progression [79,80]. It is currently unknown whether nAbs play a role in suppressing viral replication during chronic HIV-1 infection. All we do know is that the virus successfully escapes nAbs responses [81-83]. Stimulating the bNAbs production after the vaccination is a promising and important task; however, we should not forget that producing polyreactive Abs that bind autoantigens might be an extremely undesirable side effect. For more details, see Section 3.

\subsection{Antibodies against Env Epitopes}

Several papers are devoted to mapping the Ab-specificity responsible for crossneutralizing activity [84-86]. These nAbs recognize epitopes of monomeric gp120; in some cases, cross-neutralizing activity can be attributed to Abs recognizing linear epitopes 
in the membrane-proximal outer region (MPER) of gp41 [87,88]. It has been shown that the quaternary epitope at the end of the trimeric envelope structure, including loops V2 and V3, is often the target of cross-neutralizing Abs [17,32,89].

Figure 2 shows vulnerable targets of HIV-1: nAbs react with the HIV-1 Env spike, which is composed of three highly glycosylated gp120 molecules, each noncovalently linked to a transmembrane gp41 molecule. To initiate entry of the virus into cells, gp120 binds to the CD4 receptor on the cell surface [90]. One of the structurally conserved regions of Env among the various isolates is the CD4 binding site on gp120, which is required for binding with the CD4 receptor on the surface of immune cells, such as Thelper cells and monocytes. The second structurally conserved region of Env is the coreceptor binding site of gp120. Both the CD4 binding site and the coreceptor binding site are immunogenic, and numerous $m A$ bs against these Env regions have been isolated from HIV-infected patients. However, most human mAbs against these regions cannot bind the native viral Env trimer and, therefore, cannot neutralize HIV-1 [63].

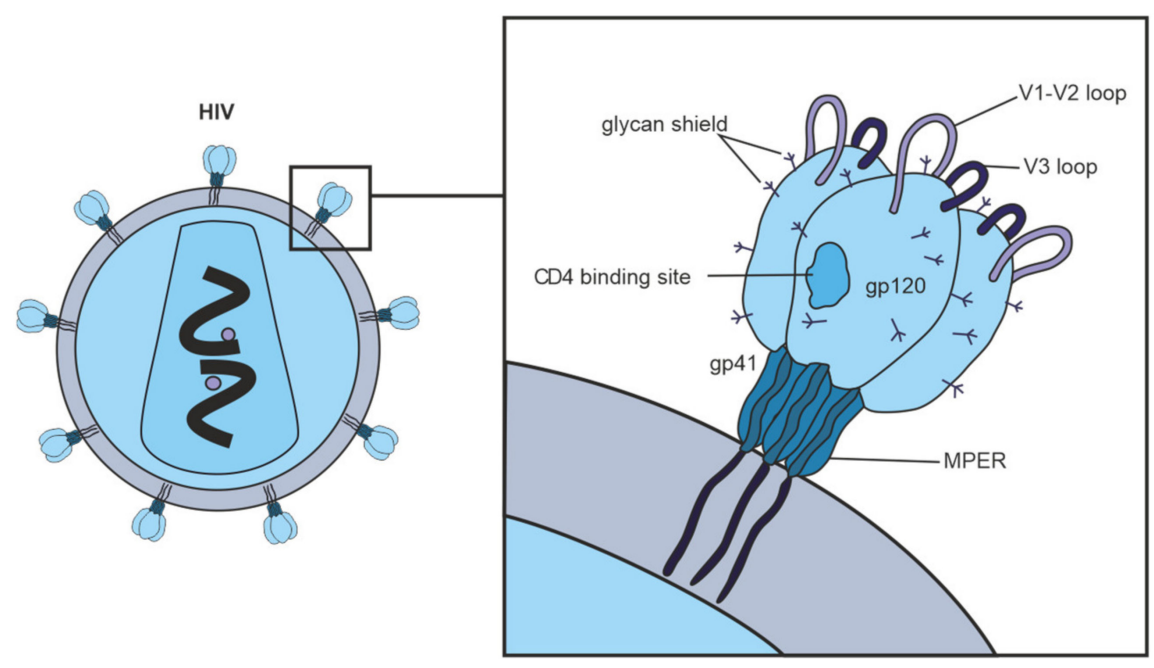

Figure 2. Vulnerable targets on trimeric glycoproteins of HIV-1 spike (gp120 and gp41). Widely neutralizing Abs target the CD4 binding site on gp120, the proximal outer membrane region of gp41, the glycan shield, and epitopes in variable loops 1, 2, and 3 on gp120.

Abs against the $\mathrm{CD} 4$ binding site of gp120 can contribute to the overall cross-neutralizing potential of HIV-positive sera; in rare cases, the broad neutralizing activity of sera is almost exclusively due to such Abs [64,86,91]. Thus, the gp120 CD4 binding site is a promising target for vaccine development.

Abs to the gp120 coreceptor binding region also contributes to some sera's crossneutralizing activity [86]. It is assumed that the coreceptor binding site is only temporarily presented to the immune system during the fusion of the virus with the cell $[70,92,93]$. Known mAbs that bind to the gp120 coreceptor binding site do not neutralize HIV-1, presumably because they cannot efficiently access this site in the trimeric viral Env [93].

MPER of gp41 is highly conserved among various strains of HIV-1. MPER participates in virus fusion with the target cell and is the target of neutralizing human Abs 2F5, Z13, and $4 \mathrm{E} 10$ [26]. It was found that only a minority of the studied sera contained anti-MPER nAbs [63]. The fact that anti-MPER Abs can be involved in neutralizing HIV-1 is noteworthy since Abs to this hydrophobic region of gp 41 can cross-react with lipid fragments on cell membranes of human cells. Therefore B cells producing such Abs can be autoreactive and likely are eliminated during B cell differentiation [94]. It is not surprising that nAbs directed against MPER rarely mediate broad and potent neutralizing activity $[17,64,86]$.

We cannot exclude that a significant part of nAbs in sera are directed to unidentified regions of the viral Env. Possibly these are quaternary epitopes created by the association of three Env molecules that form a functional Env spike on the surface of infectious viral 
particles. It is also possible that carbohydrate molecules covering large surface areas of HIV-1 Env will form such unidentified epitopes [63].

Abs that bind to Env with high affinity would be ideal for neutralizing HIV-1. Still, the high variability of the Env gene and glycosylation patterns does not allow the development of a universal antigen that will solely stimulate the production of such Abs.

\subsection{Hypervariable Domains gp 120}

HIV-1 gp120 contains five "hypervariable" domains. The first two domains (V1V2) include dramatic insertions and deletions and different glycosylation patterns [95]. The V1V2 region regulates the neutralization sensitivity of conserved epitopes such as the coreceptor binding site $[8,96,97]$. Among viruses of the B subtype, a high ratio of nonsynonymous and synonymous substitutions is characteristic of the V3 region, while in the $\mathrm{C}$ subtype, this region remains relatively conserved [98]. Abs against V3 play a minimal role in neutralizing primary viruses $[31,99]$ because the V3 loop is clogged with trimeric Env $[97,100,101]$. In contrast to V1V2, the role of V4 and V5 in neutralization resistance is unclear, although these regions affect Env conformation and glycan packaging, thereby sterically limiting the availability of neutralization determinants $[5,102,103]$.

Catalytically active Abs that hydrolyze gp120 are discussed in Section 4.1. To our knowledge, this protein is also unlikely to be a universal antigen for vaccine development.

\section{Autoantibodies in HIV-1 Infection}

Autoantibodies can interact with antigens specific to their organism. Pathogenesis of HIV / AIDS involves several factors, not a single virus-controlled destruction of CD4 ${ }^{+}$ T cells [104]; among various pathogenic mechanisms there is autoimmunity [35] directed against lymphocytes [105-107], platelets [108,109] and peripheral nerves [110,111]. Up to $40 \%$ of HIV-1-infected patients are positive for autoAbs against red blood cells [112,113], which are involved in HIV-associated autoimmune hemolytic anemia [114,115].

Circulating Abs to small nuclear ribonucleoproteins are presented in the serum of HIV-infected patients [36]. Blood serum of HIV-1-infected patients contains Abs against anticardiolipin $(\mathrm{aCL})$ and antiglycoprotein 1 (aß2GP1), anti-DNA, and antinuclear Abs [37,38]. Exact frequency of autoimmune manifestations and their pathogenesis during HIV-1 infection remain unknown. Still, it was shown that anti-aCL Abs among HIV-1-infected patients is much higher than among patients with autoimmune diseases [116]. Content of these and similar Abs among HIV-1-infected patients before antiretroviral therapy ranges from $36 \%$ to $67 \%$ [37,117]. The presence of anti-aCL Abs in blood serum is not associated with any clinical manifestations of antiphospholipid syndrome, and it is not easy to explain why [118]. Moreover, spontaneous control of HIV-1 replication or subsequent after antiretroviral therapy is associated with lower production of anti-aCL Abs $[119,120]$.

The physiological role of autoAbs generated during HIV-1 infection is not fully understood. Such autoAbs may be generated due to the "side function" of the immune system, directed to removal of autologous cells expressing foreign viral antigens (e.g., Env glycoproteins). Various HIV-1-related inflammations of the nervous system may lead to an increase of anti-MBP-Abs. General inflammation (especially in the case of chronic HIV1-infection) may lead to the apoptosis-mediated or T cell cytotoxicity-mediated increase of extracellular DNA and its complexes with histones, as well as consequent production of anti-DNA and antihistone Abs. Due to the variability of HIV-1 surface antigens and large viral load in some patients, such virus-specific Abs may be polyreactive [121,122] and recognize both viral and autologous antigens. Autoreactive Abs are often encoded by intrinsically autoreactive VH family members such as VH4-34 [123], VH1-69 [124], and others and also may provide broad neutralizing activity [125].

Among autoAbs in HIV/AIDS, Abs against DNA, histones, and MBP should be discussed separately, especially those that bind these substrates and catalyze their specific hydrolysis. 


\section{Catalytic Antibodies in HIV-1}

Autoimmune reactions and the appearance of autoAbs in HIV / AIDS and some other viral infections may be associated with the activation of polyclonal B cells, molecular mimicry between viral and/or microbial antigens and host antigens [126,127], abnormal expression of immunoregulatory molecules, and anti-idiotypic network $[38,128]$. One can propose several physiological functions of the hydrolysis of DNA, histones, and MBP by Abs. We suggest that the most relevant function of such catalytic Abs is the elimination of autoantigens formed due to the destruction of infected cells from the blood. However, we cannot exclude the possibility that such autoAbs may also explain some of the observed autoimmune pathologies found in patients with HIV / AIDS.

Activation of B-lymphocytes in HIV-1-infected patients leads to the production of Abs to viral components and autoAbs to various components of human cells [38]. It has been shown that IgG and/or IgM of patients with AIDS hydrolyze not only autoantigens as DNA [129], MBP [41], histones [40,130-132], but also viral enzymes HIV integrase $[42,43,133,134]$ and HIV reverse transcriptase [39] and corresponding peptides. Interestingly, IgG of HIV-1-infected patients efficiently cleaves five human histones (H1 [41,130], $\mathrm{H} 2 \mathrm{a}, \mathrm{H} 2 \mathrm{~b}$ [131], H3, and H4 [132]).

Some IgG preparations from patients with lymphadenopathy exhibit exceptionally high proteolytic activity, and as the disease progresses to AIDS, the percentage of patients with detectable IgG activity increases and reaches $100 \%$. Casein-hydrolyzing Abs have been found in the serum of $95 \%$ of AIDS patients and have been shown to have catalytic activity similar to serine protease [39].

It is unlikely that the HIV-1 vaccine might stimulate the generation of such autoAbs in the body of healthy patients after immunization or that vaccination sometime later will promote the generation of these Abs after HIV-1 infection. However, as shown in the following subsections, the production of some catalytic Abs is highly undesirable.

\subsection{Catalytic Antibodies Cleave gp 120}

Hydrolysis of gp120 is possessed by $\mathrm{V}$ domains of the heavy (VH) and light (VL) chains of natural IgG, IgA, and IgM $[135,136]$. A rare light chain of Abs, isolated by phage display, can bind and hydrolyze gp120 independently of the heavy chain [137]. The most described Abs catalytic sites are located in the VL domains [138].

Long-term HIV-1 infection for 5 years is associated with a modest increase in catalytic IgA against gp120 [136]. No accumulation of such Abs was observed at the earlier stages of disease (6 months) [139].

Using synthetic peptides of gp120, it was shown that amino acid residues 421-433 are required for binding to the host CD4 receptors [140]. Epitope 421-433 is relatively conserved across different strains of HIV-1 since IgM [137], IgA [136], and free light chains [141] of HIV- 1 infected patients hydrolyze peptide bond between amino acids 432-433 located within this epitope.

According to the fundamental principles of biocatalysis and the data found in the available literature, Abs that hydrolyze gp120 are unlikely to possess broad neutralizing activity. As is well known [142], catalysis and binding occur on opposite ends of a "seesaw" (in order for bNAb to exhibit neutralizing activity, effective binding is required, making it incompatible with efficient catalysis, for which highly specific binding is highly undesired). Moreover, a level of catalysis detectable in vitro or in vivo is difficult to imagine for the tightly binding Abs. We suppose that the production of Abs that hydrolyze gp120 is unlikely to be beneficial for patients.

\subsection{Antibodies Hydrolyze HIV-1 Integrase, Reverse Transcriptase, and Corresponding Oligopeptides}

$\operatorname{IgG}$ and IgM were isolated from the blood serum of HIV-1-infected patients and subsequently separated on columns with immobilized reverse transcriptase or integrase, respectively, specifically hydrolyzed only recombinant viral reverse transcriptase [39] or 
integrase [42,43]. Abs that specifically hydrolyze these HIV enzymes were of potential interest in developing new anti-HIV-1 drugs for many years.

Nearly 40 sites of HIV integrase cleavage by Abs isolated from HIV-1-infected patients were found. Most sites are located in seven known immunodominant integrase sequences [133]. Two 20 mer oligopeptides corresponding to immunogenic integrase sequences contained 9 to 10 clusters of major, moderate, and minor cleavage sites $[133,143]$. Each individual $\mathrm{Ab}$ preparation from HIV-1-infected patients had a distinct ratio of hydrolysis sites [133].

Anti-integrase Abs first cleave intergrase accumulating long fragments, further degrading these long intermediates and the formation of very short products [133]. It has been shown that anti-integrase Abs of HIV-1-infected patients effectively hydrolyze specific oligopeptides and nonspecifically tri- and tetrapeptides $[133,143]$. Moreover, catalytically active anti-integrase Abs efficiently hydrolyzed oligopeptides corresponding to the immunogenic sequences of reverse transcriptase [134] and one oligopeptide corresponding to the immunodominant region of MBP [144].

Catalytic Abs are highly specific for globular proteins, but some of them can effectively cleave nonspecific tri- and tetrapeptides $[134,145,146]$. Catalytic sites of proteolytic Abs are usually located in the $\mathrm{VL}$, while the heavy chain is responsible for specific antigen recognition and increasing antigen- $\mathrm{Ab}$ affinity. It is not surprising that the active center of anti-integrase Abs is located on the light chains [42,43].

The affinity of Abs to short oligopeptides is $100-1000$ times lower than for the corresponding globular proteins $[134,145,147]$. Therefore, depending on the amino acid sequence, hydrolysis of oligopeptides with Abs is less specific or completely nonspecific $[133,143]$.

The physiological function of the hydrolysis of enzymes involved in HIV nucleic acid metabolism (i.e., reverse transcriptase and integrase) by catalytic Abs is unknown. It is postulated that Abs can penetrate the cell nucleus and function as proteases therein $[148,149]$, but these processes have never been shown in vivo in the case of HIV-1 infection. According to some reports, the generation of such catalytic Abs may positively affect HIV patients [150]. Since the production of catalytic Abs can be stimulated by immunization with transition states of a chemical reaction, the use of substances such as immunogens may be of particular interest in designing HIV-1 vaccines. Unfortunately, no single case was found where/wherein such catalytic activity was shown for the bNAbs.

\subsection{Antibodies Hydrolyze DNA, Histones, and Myelin Basic Protein}

Relative DNase activity of Abs isolated from the blood serum of HIV-1-infected donors varies significantly from patient to patient, but $96 \%$ of the preparations show a detectable level of DNase activity [129], which is an intrinsic feature of Abs [39]. Abs against H1, H3, $\mathrm{H} 4$, and MBP possess enzymatic cross-reactivity [151]: anti-histone H1 IgG hydrolyze H1 as well as MBP, and vice versa, anti-MBP Abs hydrolyze this H1 histone [41]. Similarly, IgG against $\mathrm{H} 2 \mathrm{a}$ and $\mathrm{H} 2 \mathrm{~b}$ histones efficiently hydrolyze these histones and MBP, and antiMBP Abs cleave MBP, H2a, and H2b histones, but not other control proteins [151]. Near $100 \%$ of IgG of HIV-infected patients effectively hydrolyze between one and five human histones [40].

Table 1 presents data on all currently known to authors on catalytic Abs in HIV/AIDS. 
Table 1. The catalytic activity of natural Abs isolated from the blood serum of HIV-1-infected patients, their substrates, and individual epitopes.

\begin{tabular}{ccc}
\hline Specific Substrate & Type of Abs (Ab Fragment) & Ref \\
\hline gp120 & L-chain, IgA & {$[136-138]$} \\
epitope 421-433 of gp120 & IgM, IgA, L-chain & {$[136,137,141]$} \\
HIV-1 integrase & IgG, IgM & {$[42,43]$} \\
HIV-1 integrase oligopeptides & IgG, IgM & {$[133,143]$} \\
HIV-1 reverse transcriptase & IgG, IgM & {$[39]$} \\
HIV-1 reverse transcriptase oligopeptides & IgG, IgM & {$[134]$} \\
$\beta$-casein & IgG & {$[39]$} \\
DNA & IgG, L-chain & {$[39,152]$} \\
histones & IgG & {$[40]$} \\
MBP & IgG & {$[41]$} \\
MBP oligopeptides & IgG & {$[144]$} \\
short non-specific oligopeptides & IgG & {$[133]$} \\
\hline
\end{tabular}

It is challenging to explain binding polyspecificity and catalytic polyreactivity of natural anti-MBP and antihistone Abs in HIV / AIDS only by the similarity of these antigens. It is known that anti-MBP and antihistone Abs play a negative role in the pathogenesis of systemic lupus erythematosus and multiple sclerosis [153-155]. These catalytic Abs may possess a wide range of physiological functions, such as clearing the blood of HIV-infected patients from excess autoantigens formed due to cell destruction. We assume that these catalytic autoAbs are highly undesirable, and their possible generation should be strictly avoided when designing prospective vaccines.

\section{HIV-1 Vaccines: Production of Neutralizing Antibodies}

Current HIV-1 prevention and treatment strategies include using antiretroviral drugs for pre-exposure prophylaxis and antiretroviral therapy. This made it possible to transform HIV-1 from a life-threatening disease to a manageable chronic disease [156]. However, drugs are expensive, require strict dosing to be effective, and cause side effects. Some HIVinfected patients develop drug resistance; furthermore, drug access remains a significant barrier, especially in low- and middle-income countries. Thus, a preventive vaccine remains a central component of a multidimensional strategy to end the HIV-1 epidemic. However, developing an effective vaccine against HIV-1 has proven to be a daunting task. To date, there is still no single approved HIV-1 vaccine, and only one promising clinical trial (the "Thai" trial of RV144) has shown a modest 31\% efficacy [157].

HIV-1 replicates chronically in the host and evades an Ab response, unlike other viral pathogens. Immunity evasion and large genetic variation among HIV-1 strains are significant obstacles to vaccine development. The use of vaccines should provide generation of Abs that can adapt to the Env glycan screen and bind to various viral strains to offer complete protection $[158,159]$. An ideal HIV-1 vaccine would elicit serum Abs that are highly effective and can prevent viral infection at low concentrations and have broad action-making a high percentage of hard-to-neutralize viruses inactive [160].

HIV-1 vaccine should induce both humoral and cellular immunity. Abs neutralizing the virus will provide the first layer of defense by preventing infection of host cells as the virus enters the body. When some virions start to escape nAbs, cytotoxic $C D 8^{+} \mathrm{T}$ cells will provide a secondary level of protection, eliminating the earliest infected cells preventing the generation of the latent reservoir of HIV-1-infected cells [161]. Table 2 shows all current completed HIV-1 vaccine studies. 
Table 2. Completed HIV-1 vaccine studies according to the clinicaltrials.gov website.

\begin{tabular}{|c|c|c|}
\hline Title & Conditions & ID \\
\hline HIV Testing \& Womens Attitudes on HIV Vaccine Trials & HIV-1 & NCT00771537 \\
\hline Efficacy and Safety of GSK Biologicals HIV Vaccine in & & \\
\hline $\begin{array}{l}\text { Antiretroviral Therapy (ART)-naïve HIV Infected } \\
\text { Persons }\end{array}$ & HIV-1 & NCT01218113 \\
\hline Follow up of Thai Adult Volunteers With Breakthrough & & \\
\hline $\begin{array}{l}\text { HIV Infection After Participation in a Preventive HIV } \\
\text { Vaccine Trial }\end{array}$ & HIV-1 & NCT00337181 \\
\hline Study to Optimize the Quality of Samples for & & \\
\hline $\begin{array}{l}\text { Cell-mediated Immunity (CMI) in ART-naïve } \\
\text { HIV-infected Subjects }\end{array}$ & HIV-1 & NCT01610427 \\
\hline HIV Vaccine Trial in Thai Adults & HIV-1 & NCT00223080 \\
\hline $\begin{array}{l}\text { A Safety and Immune Response Study of } 2 \\
\text { Experimental HIV Vaccines }\end{array}$ & HIV-1 & NCT02404311 \\
\hline $\begin{array}{l}\text { Safety and Immunogenicity of Clade C ALVAC and } \\
\text { gp120 HIV Vaccine }\end{array}$ & HIV-1 & NCT03284710 \\
\hline $\begin{array}{l}\text { The Safety and Immunogenicity of a Potential HIV } \\
\text { Vaccine }\end{array}$ & HIV-1 & NCT01966900 \\
\hline $\begin{array}{l}\text { Investigation of V520 in a HIV Vaccine Dose Refinement } \\
\text { Study (V520-027) }\end{array}$ & HIV-1 & NCT00350623 \\
\hline $\begin{array}{l}\text { Investigation of V520 in an HIV Vaccine } \\
\text { Proof-of-Concept Study (V520-023) }\end{array}$ & HIV-1 & NCT00095576 \\
\hline $\begin{array}{l}\text { Dose-ranging Study to Evaluate the Safety \& } \\
\text { Immunogenicity of a HIV Vaccine } 732,461 \text { in Healthy } \\
\text { HIV Seronegative Volunteers }\end{array}$ & HIV-1 & NCT00434512 \\
\hline $\begin{array}{l}\text { Effectiveness of Two Hepatitis B Vaccines in } \\
\text { HIV-negative Youths }\end{array}$ & Hepatitis B & NCT00107042 \\
\hline $\begin{array}{l}\text { A Pilot Study of a Dendritic Cell Vaccine in HIV-1 } \\
\text { Infected Subjects }\end{array}$ & HIV-1 & NCT00833781 \\
\hline $\begin{array}{l}\text { HIV-1 Peptide Immunization of Individuals in West } \\
\text { Africa to Prevent Disease }\end{array}$ & HIV-1 & NCT01141205 \\
\hline Therapeutic Vaccine for HIV & HIV-1 & NCT01859325 \\
\hline $\begin{array}{l}\text { Safety and Immunogenicity of Anti-Pneumococcal } \\
\text { Vaccines in HIV-Infected Pregnant Women }\end{array}$ & Pneumococcal & NCT02717494 \\
\hline $\begin{array}{l}\text { H1N1 Influenza Vaccine Immunogenicity in HIV-1 } \\
\text { Infected Patients }\end{array}$ & HIV-1 & NCT01111162 \\
\hline $\begin{array}{l}\text { Impact of a Human Papilloma Virus (HPV) Vaccine in } \\
\text { HIV-Infected Young Women }\end{array}$ & HIV-1 & NCT00710593 \\
\hline $\begin{array}{l}\text { Safety and Effectiveness of HIV-1 DNA Plasmid Vaccine } \\
\text { and HIV-1 Recombinant Adenoviral Vector Vaccine in } \\
\text { HIV-Uninfected, Circumcised Men and Male-to-Female } \\
\text { (MTF) Transgender Persons Who Have Sex With Men }\end{array}$ & HIV-1 & NCT00865566 \\
\hline $\begin{array}{l}\text { A Study of Safety, Tolerability, and Immunogenicity of } \\
\text { the MRKAd5 Gag/Pol/Nef Vaccine in Healthy Adults } \\
\text { (V520-016) }\end{array}$ & HIV-1 & NCT00849680 \\
\hline $\begin{array}{l}\text { Improving Immunogenicity of Influenza Vaccine in HIV } \\
\text { Infected Individuals }\end{array}$ & HIV-1 & NCT01262846 \\
\hline $\begin{array}{l}\text { Immunogenicity of Hepatitis B Vaccination in } \\
\text { HIV-infected Adults }\end{array}$ & Hepatitis B & NCT03316807 \\
\hline $\begin{array}{l}\text { Immune Responses to Pneumococcal Vaccination } \\
\text { Among HIV-infected Subjects }\end{array}$ & HIV-1 & NCT00706550 \\
\hline $\begin{array}{l}\text { Long-term Immunogenicity of the HIV } \\
\text { gp120-NefTat/AS01B Vaccine (GSK SB732461) }\end{array}$ & HIV-1 & NCT03368053 \\
\hline $\begin{array}{l}\text { Early Versus Delayed BCG Vaccination of } \\
\text { HIV-exposed Infants }\end{array}$ & HIV-1 & NCT00712530 \\
\hline $\begin{array}{l}\text { Combination Vaccination Before HIV Treatment } \\
\text { Interruption }\end{array}$ & HIV-1 & NCT02062580 \\
\hline
\end{tabular}


Table 2. Cont.

\begin{tabular}{|c|c|c|}
\hline Title & Conditions & ID \\
\hline $\begin{array}{l}\text { Evaluating the Immunogenicity of the AIDSVAX B/E } \\
\text { Vaccine and the MVA/HIV62B Vaccine in Healthy, } \\
\text { HIV-1-Uninfected Adults Who Previously Received } \\
\text { MVA/HIV62B in DNA/MVA or MVA/MVA Regimens } \\
\text { in HVTN } 205\end{array}$ & HIV-1 & NCT02852005 \\
\hline $\begin{array}{l}\text { Evaluation of Safety and Immunogenicity of a Human } \\
\text { Papillomavirus (HPV) Vaccine in Human } \\
\text { Immunodeficiency Virus (HIV) Infected Females }\end{array}$ & HPV-1 & NCT01031069 \\
\hline $\begin{array}{l}\text { Immunogenicity of Fluzone HD, A High Dose Influenza } \\
\text { Vaccine, In Children With Cancer or HIV } \\
\text { Shedding, Immunogenicity and Safety of Quadrivalent }\end{array}$ & HIV-1 & NCT01205581 \\
\hline $\begin{array}{l}\text { Live Intranasal Influenza Vaccine (QLAIV) in } \\
\text { HIV-infected Children and Young Adults }\end{array}$ & HIV-1 & NCT02474901 \\
\hline $\begin{array}{l}\text { Live Zoster Vaccine in HIV-Infected Adults on } \\
\text { Antiretroviral Therapy }\end{array}$ & Herpes Zoster & NCT00851786 \\
\hline $\begin{array}{l}\text { Safety of and Immune Response to an H1N1 Influenza } \\
\text { Virus Vaccine in HIV Infected Children and Youth }\end{array}$ & $\begin{array}{l}\text { H1N1 } \\
\text { Influenza }\end{array}$ & NCT00992836 \\
\hline $\begin{array}{l}\text { Safety and Immune Response of a Rotavirus Vaccine in } \\
\text { HIV-infected and Uninfected Children Born to } \\
\text { HIV-infected Mothers }\end{array}$ & Rotavirus & NCT00880698 \\
\hline $\begin{array}{l}\text { Safety and Immunogenicity of } 13 \text {-Valent Pneumococcal } \\
\text { Conjugate Vaccine }(13 v P n C) \text { in HIV-Infected Subjects } 6 \\
\text { Years of Age or Older Who Are } € \text { to Pneumococcal } \\
\text { Vaccine }\end{array}$ & Pneumococcal & NCT00962780 \\
\hline $\begin{array}{l}\text { Safety of and Immune Response to an H1N1 Influenza } \\
\text { Vaccine in HIV Infected Pregnant Women }\end{array}$ & $\begin{array}{l}\text { H1N1 } \\
\text { Influenza }\end{array}$ & NCT00992017 \\
\hline $\begin{array}{l}\text { Immunization With HIV-1 Peptides in Adjuvant for } \\
\text { Treatment of Patients With Chronic HIV-infection }\end{array}$ & HIV-1 & NCT01009762 \\
\hline $\begin{array}{l}\text { Safety and Immunogenicity of IMVAMUNE (MVA-BN) } \\
\text { Smallpox Vaccine in HIV Infected Patients }\end{array}$ & HIV-1 & NCT00316589 \\
\hline Autologous Dendritic Cell Vaccine in HIV1 Infection & HIV-1 & NCT00510497 \\
\hline $\begin{array}{l}\text { Quadrivalent HPV Vaccine to Prevent Anal HPV in } \\
\text { HIV-infected Men and Women }\end{array}$ & HIV-1 & NCT01461096 \\
\hline $\begin{array}{l}\text { Safety of and Immune Response to the Human } \\
\text { Papillomavirus (HPV) Vaccine in HIV-Infected Women }\end{array}$ & HPV-1 & NCT00604175 \\
\hline $\begin{array}{l}\text { Comparison of Three Hepatitis B Vaccination Regimens } \\
\text { in HIV-Positive Youth }\end{array}$ & Hepatitis B & NCT00106964 \\
\hline $\begin{array}{l}\text { Safety of and Immune Response to a Novel Human } \\
\text { Papillomavirus Vaccine in HIV Infected Children }\end{array}$ & HPV & NCT00339040 \\
\hline $\begin{array}{l}\text { Safety of and Immune Response to a Meningitis Vaccine } \\
\text { in HIV Infected Children and Youth }\end{array}$ & Meningitis & NCT00459316 \\
\hline $\begin{array}{l}\text { Safety and Efficacy of Romidepsin and the Therapeutic } \\
\text { Vaccine Vacc- } 4 x \text { for Reduction of the Latent HIV-1 } \\
\text { Reservoir }\end{array}$ & HIV-I & NCT02092116 \\
\hline $\begin{array}{l}\text { Safety and Immunogenicity of GlaxoSmithKline } \\
\text { Biologicals' HPV Vaccine 580,299 (Cervarix) in HIV } \\
\text { Infected Females }\end{array}$ & HPV & NCT00586339 \\
\hline $\begin{array}{l}\text { The Effect of HPV Vaccination on Recurrence Rates in } \\
\text { HIV Patients With Condylomata } \\
\text { Immune Response After Booster Vaccination in }\end{array}$ & HPV & NCT00941889 \\
\hline $\begin{array}{l}\text { HIV-Infected Patients Who Received Rabies Primary } \\
\text { Vaccination }\end{array}$ & Rabies & NCT01286493 \\
\hline $\begin{array}{l}\text { Safety and Immunogenicity of a Candidate Tuberculosis } \\
\text { (TB) Vaccine in HIV-positive Adults. }\end{array}$ & Tuberculosis & NCT00707967 \\
\hline $\begin{array}{l}\text { Safety \& Immunogenicity of } 13 \mathrm{vPnC} \text { in HIV-Infected } \\
\text { Subjects Aged } 18 \text { or Older Who Were Previously } \\
\text { Immunized With 23vPS }\end{array}$ & Pneumococcal & NCT00963235 \\
\hline
\end{tabular}


Table 2. Cont.

\begin{tabular}{|c|c|c|}
\hline Title & Conditions & ID \\
\hline $\begin{array}{l}\text { Study to Evaluate GSK Biologicals' Herpes Zoster } \\
\text { Vaccine GSK1437173A in Human Immunodeficiency } \\
\text { Virus HIV Infected Subjects }\end{array}$ & Herpes Zoster & NCT01165203 \\
\hline $\begin{array}{l}\text { Vaccine Therapy in Preventing HPV in HIV-Positive } \\
\text { Women in India }\end{array}$ & HPV & NCT00667563 \\
\hline $\begin{array}{l}\text { Evaluation of the Immune Response of a HIV Candidate } \\
\text { Vaccine After Administration of One Chloroquine Dose }\end{array}$ & HIV-1 & NCT00972725 \\
\hline $\begin{array}{l}\text { Evaluating the Safety and Immunogenicity of HIV } \\
\text { Clade C DNA Vaccine and MF59- or AS01B-Adjuvanted } \\
\text { Clade C Env Protein Vaccines in Various Combinations } \\
\text { in Healthy, HIV-Uninfected Adults }\end{array}$ & HIV-1 & NCT02915016 \\
\hline $\begin{array}{l}\text { Safety and Immunogenicity of GSK Biologicals' } \\
\text { Investigational Malaria Vaccine in HIV Infected Infants } \\
\text { and Children }\end{array}$ & Malaria & NCT01148459 \\
\hline $\begin{array}{l}\text { Magnitude of the Antibody Response to and Safety of a } \\
\text { GBS Trivalent Vaccine in HIV Positive and HIV } \\
\text { Negative Pregnant Women and Their Offsprings } \\
\text { Vaccine Therapy in Preventing Human Papillomavirus }\end{array}$ & Streptococcal & NCT01412801 \\
\hline $\begin{array}{l}\text { Infection in Young HIV-Positive Male Patients Who } \\
\text { Have Sex With Males }\end{array}$ & HPV & NCT01209325 \\
\hline $\begin{array}{l}\text { Primary and Booster Vaccination Study With a } \\
\text { Pneumococcal Vaccine in HIV Infected, HIV Exposed } \\
\text { Uninfected and HIV Uninfected Children } 6 \text { to } 10 \text { Weeks } \\
\text { of Age. }\end{array}$ & Pneumococcal & NCT00829010 \\
\hline $\begin{array}{l}\text { Intradermal Versus Intramuscular Polio Vaccine Booster } \\
\text { in HIV Infected Subjects }\end{array}$ & Polio & NCT01686503 \\
\hline $\begin{array}{l}\text { Human Papillomavirus Vaccine Therapy in Treating } \\
\text { Men With HIV-1 Infection }\end{array}$ & HPV & NCT00513526 \\
\hline $\begin{array}{l}\text { MRKAd5 HIV-1 Gag Vaccine (V520) in Subjects With } \\
\text { Chronic Hepatitis C (V520-022) }\end{array}$ & Hepatitis C & NCT00857311 \\
\hline
\end{tabular}

\subsection{HIV-1 Vaccine Development Strategies}

The induction of a protective $\mathrm{Ab}$ response remains the main priority in developing HIV-1 vaccines [162]. Unfortunately, most current HIV-1 vaccine candidates do not elicit nAbs against most circulating viral strains. To replicate chronically in the host, the HIV1 uses several mechanisms to defend itself against Ab recognition: Env glycoprotein is protected by the shield of glycans. Different variations occur in immunodominant loops, and key viral epitopes are due to the conformational lability [5,21,56] (Figure 3). These defense mechanisms, although very effective, have vulnerabilities; information on the precise location and molecular structure of these vulnerable regions can be useful for the rational design of improved vaccine immunogens.

Another line of research is related to the stimulation of the immune response on the mucous membranes. It has been shown that bNAbs can neutralize most virus strains in a cross-over manner and provide reliable mucosal protection in a monkey model [163-165].

In addition, induction of cytotoxic $\mathrm{T}$ cells has become a favored strategy for HIV1 vaccination. Cytotoxic T cells can lyse infected cells and hold HIV-1 after infection. However, $\mathrm{T}$ cells do not inactivate free viral particles. Moreover, cytotoxic $\mathrm{T}$ cell response cannot adapt to the escape mutants resistant to vaccine-induced immunity [166].

Strategies for developing vaccines based on Abs to the variable domains of gp120 were abandoned, since such Abs only provide strain-specific neutralizing activity [167]. 
(A) Focusing on conserved epitopes

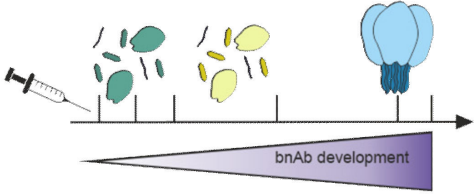

(B) Overcoming viral diversity

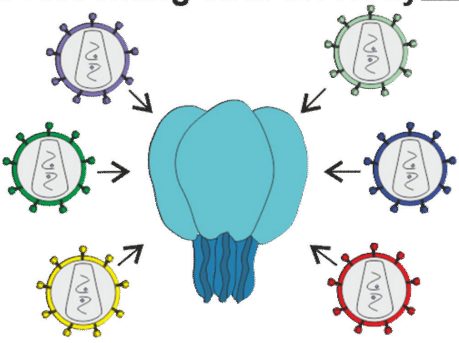

(C) Mimicking natural infection

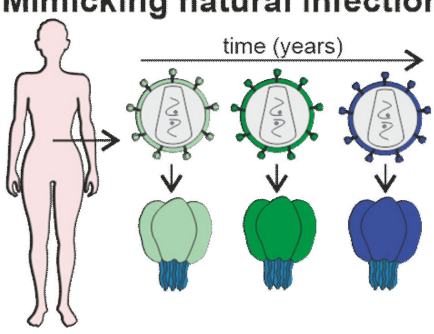

(D) Targeting bnAbs B-cell precursors

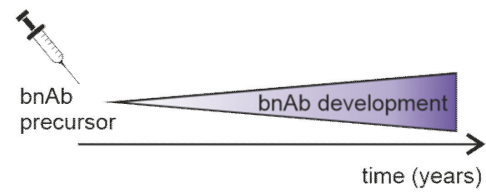

\section{(E) Utilizing glycan holes}

bnAbs

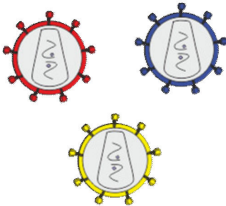

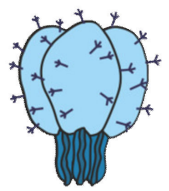

Figure 3. Several strategies are currently used to stimulate $\mathrm{nAb}$ responses towards bnAb generation, which consist of (A) directing of $\mathrm{Ab}$ response to conserved sites, for example, using fusion peptides; (B) use of mosaic or consensus antigens to overcome the viral diversity of circulating HIV-1 worldwide; (C) clonal immunogens resembling the evolution of the virus in HIV-1 infected individuals modeling natural infection; (D) targeting immunogens to putative bnAb germline progenitors, followed by immunization leading to the affinity maturation pathway to bnAb developm€; (E) selective removing of glycans to focus $\mathrm{Ab}$ responses to a specific site of interest, such as CD4 binding site immunogens.

Recent discoveries have generated interest in "non-neutralizing" Abs that cannot directly inhibit the entry of the free virus into target cells but exhibit antiviral activity mediated by the $\mathrm{Fc}$ region of the $\mathrm{Ab}$ molecule. These $\mathrm{Ab}$ effector mechanisms include complement binding and viral lysis, phagocytosis of $\mathrm{Ab}$-coated virions, and $\mathrm{Ab}$-dependent cellular cytotoxicity [168-170].

Today, we do not understand the regulatory pathways of B cells completely. Additional information on the mechanisms responsible for migration, selection, and differentiation 
of B cells can be valuable to target appropriate Env epitopes to the specific pathways of B cell induction [67]. Most studies of humoral responses to HIV-1 infection have examined Abs, the final product of B cell response. Relatively few studies have examined the immunopathogenesis of B cells. However, several fundamental questions remain unanswered.

\subsection{Immunogen Structure Design}

HIV-1 predominantly induces non-neutralizing or strain-specific Abs during the first months after infection [5,70]. It was found that approximately 10-20\% of HIV-1-infected patients had bNAbs after a few years of disease $[17,63,170]$, which is the humoral immune response that a vaccine should elicit.

Viral epitopes conserved among most viral strains are more likely to generate crossreactive Abs. In this regard, research is focused on small numbers of human mAbs isolated from HIV-1-infected individuals that possess cross-reactive neutralizing activity $[56,81]$. However, these conserved viral epitopes are weakly immunogenic or produce Abs with limited reactivity. Minor structural changes may improve specific binding [20,67]. The crystal structure of b12 mAb bound to the CD4 receptor binding site of the gp120 molecule provides insight into how $\mathrm{nAbs}$ gain access to the functionally conserved regions of the Env glycoprotein [34]. A better understanding of the gp120 and gp120-gp41 complexes structure and binding of Abs to the Env glycoprotein may provide new insights into the development of vaccines. Efforts to stabilize gp120 in a more immunogenic form and create a scaffold of conservative neutralizing epitopes may lead to more effective $\mathrm{Ab}$ responses [67].

One of the promising strategies for generating bNAbs after vaccination is the use of naïve B cells with long heavy chain complementarity-determining regions (HCDR3). These long HCDR3s are generated at the stage of V(D)J recombination [171] and are selected by Env, which results in the production of bNAbs targeting conserved epitopes [172]. BG18 is one such example [173]: it contains HCDR3 that does not have insertions or deletions since it can be easily induced in vivo [174]. Other long HCDR3s are described in rare B cells of HIV-1-naïve individuals, which binds to gp120 and neutralize the virus [175]. Interestingly, polyreactive BCRs may also contain long HCDR3; some other data suggests that bNAbs are intrinsically poly- or autoreactive and might be products of aberrations of immune tolerance controls [176].

Detailed molecular and immunological studies of the autologous neutralization response would improve the understanding of viral determinants vulnerable to $\mathrm{Ab}$ attack. Of particular interest are epitopes that direct autologous nAbs in HIV-1-infected patients. These epitopes can be highly variable, but apparently, there is no limit to the degree of variability that HIV-1 can exhibit in these regions $[177,178]$.

One of the problems of induction of bNAbs is the limitation of suitable immature B cells, which may express BCR encoded by intrinsically autoreactive $\mathrm{VH}$ genes or contain long HCDR3 [179]. Moreover, these cells may not be ready for activation even by optimally engineered HIV-1 immunogen due to the B cell tolerance [180]. As a result of their intrinsic autoreactivity, these B cells may undergo negative selection in germinal centers [181]. Finally, unrestricted accessibility of an optimally engineered HIV-1 immunogen to these B cells may trigger severe autoimmunity, which is highly undesirable.

\subsection{Vaccination Inducing Immune Response at Mucous Membranes}

Mucosal tissues of the gastrointestinal tract and vagina are the main reservoirs for the initial replication and reproduction of HIV-1, as well as sites of rapid depletion of CD4 ${ }^{+} \mathrm{T}$ cells [182]. Such viral reservoirs are considered significant difficulties in eradicating HIV-1 in infected hosts. A successful vaccine should prevent the creation of these reservoirs at a very early stage of HIV-1 infection [183]. Protection of mucous membranes from HIV-1 is mainly provided due to the Abs. Vaccination is not necessarily resulting in extremely high levels of $\mathrm{nAb}$ to protect the mucosal surface. Still, the Ab response must be robust, and $\mathrm{nAb}$ must cross-react with the genetically diverse spectra of HIV-1 [184]. 
IgA is the predominant $\mathrm{Ab}$ isotype in most human mucosal secretions [185]. It has been reported that dimeric IgA applied rectally can not only protect against the rectal route of HIV-1 infection but be more effective than the corresponding IgG [186]. Several studies on humans have also found a correlation between high levels of secretory $\operatorname{Ig} \mathrm{A}(\mathrm{S} \operatorname{Ig} \mathrm{A})$ and protection in high-risk individuals who remain seronegative $[187,188]$.

Systemically delivered viral vectors can induce a mucosal immune response against HIV, especially in the intestinal, rectal, and genital mucosa $[189,190]$, but the strength of these responses is usually low. After systemic immunization, adenoviral vector vaccines induce low mucosal immune responses [184]. However, very few vaccines provide mucosal immunity against any infectious disease [191].

It is known that nasal introduction of vaccine results in the generation of Abs in the respiratory system mucosa and saliva and nasal secretions, but not in the gut or vagina [192]. Vaginal vaccination should be administered on specific days of the cycle and therefore might not be optimal for general use [193]. Protective immunity against HIV-1 was demonstrated after oral administration of the gp120-based vaccine [194]. Since most homosexual and vertical transmission of HIV-1 occurs via the gastrointestinal tract [193], HIV-1 vaccines, delivered to the mucosal tissues, are very effective in generating gut immunity, making the oral way of HIV-1 mucosal vaccine delivery highly perspective.

One promising approach to stimulate mucosal immunity after vaccination is virus-like particle (VLP) vaccines. VLP are genomic-free viral particles (pseudovirions) produced by the spontaneous assembly of viral capsid proteins. They are similar in size and structure to intact virions, but they do not replicate and are pathogenic. These immunogens can be administered as purified DNA particles or plasmids expressing viral proteins required for in vivo VLP formation $[195,196]$. Several successful VLP vaccines have been developed against sexually transmitted HPV (human papillomavirus) and tested in human trials (flu), demonstrating the potential efficacy of VLP as candidates for an HIV-1 vaccine $[197,198]$.

Since the digestive tract is permanently faced with a substantial antigenic load, the problem of efficient induction of mucosal $\mathrm{Ab}$ response and avoidance of mucosal tolerance after antigen introduction is crucial. Anti-HIV-1 vaccination of immunologically naïve patients may have an undesirable effect in decreasing cytotoxic $\mathrm{T}$ lymphocyte immunity. Since the other mucosal vaccines (against the poliovirus, influenza, and other viruses) possess protective effects as the result of Abs generation, but not via the cytotoxic $\mathrm{T}$ lymphocytes, this problem is especially relevant in the case of HIV-1 vaccines [199].

The human gut contains various commensal microbes, its disruption after oral vaccination could, in theory, lead to severe diseases, such as inflammatory bowel disease. Use of adjuvants or other vaccine components [200] may attenuate intestinal tolerance, increase intestinal immunity [201], and lead to the inflammatory response or dysbiosis. These problems should be considered during the development of prospective oral HIV-1 vaccines. Since eight oral vaccines against cholera, salmonella, influenza virus, poliovirus, and rotavirus are currently licensed for use in humans [202], this brings closer the perspective of the development of the HIV-1 oral vaccine.

\subsection{Covalent Epitope-Based Vaccines}

Although the virus mutates rapidly, it must retain specific surface protein epitopes to maintain its infectivity. Inducing a robust immune response against structurally conserved epitopes essential to the viral life cycle is a logical route to a vaccine development that will be effective worldwide and minimize the possibility of viral mutants' escape. The target site should be expressed on the surface of free virions in a form that is sterically accessible to Abs. The main problem is that the vulnerable epitopes of HIV-1 are weakly immunogenic. Peptide immunogens with sequences identical to the linear conserved epitopes of gp120 can be easily synthesized, but the conformation of such peptides may also differ from that of the native epitope. Conformational states of the non-native peptide induce Abs with useless, non-neutralizing specificity. Conformational mimicry of discontinuous epitopes taken from conserved regions of gp120 has been hampered by the limitations of modern 
physicochemical methods for accurately assessing the structure and dynamics of a protein binding to Abs. Therefore, until recently, no promising epitope-based vaccine candidate has emerged [48].

Rare mAbs against gp120 and gp41 have a relatively broad neutralizing activity, for example: b12 [34], 2G12 [203] and 2F5 [27]. Abs common to these mAbs are not detectable in the polyclonal $\mathrm{Ab}$ mixture present in the blood of HIV-infected humans or animals immunized with experimental immunogens. Certain coreceptor binding site epitopes that are sterically inaccessible to Abs become exposed after gp120 binds to CD4. The temporary presentation of such epitopes on the surface of the gp120 protein limits their effect on Abs generation. It is encouraging that the exposed conserved epitope at the coreceptor binding site of the CD4-independent form of gp120 is immunogenic enough to induce extensive neutralization of Abs [48]. CD4 binding site 421-433 region is the notorious Achilles heel of the virus. Production of Abs to this area by traditional B cell differentiation pathways does not occur, but when anti-421-433 Abs appear, they neutralize various viral strains with exceptional efficiency $[204,205]$. Despite the difficulties described above, we suggest that the covalent epitope-based vaccines are promising direction of HIV-1 vaccine development.

\subsection{HIV-1 mRNA Vaccines}

The SARS-CoV-2 pandemic introduced the world to a new type of vaccine-mRNA encapsulated in lipid nanoparticles. mRNA-based vaccines rely on the production of individual immunogens by the host cells, which in turn are targets for $\mathrm{Ab}$ responses and cytotoxic T cells [206]. Traditional subunit vaccines deliver immunogens in a protein that degrades immediately after injection. In contrast, mRNA-based vaccines induce weekly production of immunogens in situ [207], increasing the possibility that rare bnAb progenitor $\mathrm{B}$ cells will become activated and proliferate after immunization. Prolonged production of mRNA-encoded immunogens in vivo works much like antigen release via an osmotic pump. Slow antigen delivery increases the activity of the germinal center and the induction of HIV-1 nAbs [208].

Strategies that increase the immunogenicity of Env antigens increase the chance of activation of rare $\mathrm{B}$ cells carrying germline progenitors with bnAb potential. One approach to improve the immunogenicity of Env is to map the Env immunogens onto arrays of particles such as nanoparticles or virus-like particles [209,210]. An antigen multimerization technique that lends itself to the mRNA platform of the vaccine is to encode a self-assembling scaffold protein, such as a ferritin nanoparticle, in addition to the Env immunogen [211]. Multimerization of Env on ferritin nanoparticles improves the immunogenicity of Env in animal models [212,213], thereby enhancing the activation of rare and/or anergic germline precursors of bnAb.

Although research and development innovations have led to rapid advances in mRNA vaccines over the past few years, many unresolved questions and challenges remain in developing an mRNA-based HIV-1 vaccine. There is no comprehension of the mechanisms of mRNA immunogenicity. Mainly, which cells express mRNA and produce the encoded immunogen? How do the immunogens encoded by mRNA interact with various immune system cells? What are the kinetics and magnitude of expression of the immunogen encoded by mRNA in vivo, especially with complex HIV-1 antigens? The answers to these questions will provide significant guidance for developing and evaluating mRNA-based HIV-1 vaccines [214].

Another problem is that correctly folded Env trimers can be purified before immunization in vaccines containing protein subunits. However, when Env immunogen is delivered as mRNA, it is impossible to purify protein trimers. To overcome the problem, the strategy of Env stabilization in cells needs to be developed [215-217].

Another critical issue in developing an HIV-1 immunogen for mRNA vaccination is associated with the inevitable post-translational modification in the host cell [218]. At an early stage of immunogen design, it is essential to consider the shape of the protein product encoded by the mRNA produced by the host cells. The global success of the SARS-CoV-2 
mRNA vaccines allows us to dream that this perspective approach can design an HIV-1 vaccine, stimulating the generation of $\mathrm{bNAbs}$, considering the limitations described above.

\section{Immune Exhaustion and Antibody Response}

Immune exhaustion is the loss of effector functions and proliferative capacity of memory T cells [219]. The process of immune exhaustion in the context of persistent viral infections was first described in a mouse model of lymphocytic choriomeningitis (LCMV). It has been shown that LCMV-specific $\mathrm{CD}^{+} \mathrm{T}$ cells are preserved during chronic infection but are not cytotoxic [220]. Subsequently, T cell exhaustion has been described in patients with chronic viral infections such as HIV-1, hepatitis B, and hepatitis C [221-223].

Immune exhaustion was described for both $\mathrm{CD}^{+}$and $\mathrm{CD}^{+} \mathrm{T}$ cells [224,225]. Antigenspecific exhaustion of effector and memory cells includes a gradual loss of effector function and proliferative capacity, which progress until such cells are eliminated [226]. Exhausted $\mathrm{CD}^{+} \mathrm{T}$ cells significantly differ from terminally differentiated or memory $\mathrm{CD} 8^{+} \mathrm{T}$ cells: they secrete fewer cytokines and are characterized by cell surface expression of inhibitory receptors such as PD-1, CTLA4, Tim3, TIGIT, CD160, and LAG-3 [227-229]. Such surface expression of inhibitory receptors increases upon activation and limits the overactivation of T cells, providing the so-called immune checkpoints (IC) [224].

HIV-specific CD8 ${ }^{+}$T cells upregulate PD-1 expression in untreated infection as their effector function declines. PD-1 is also activated on HIV-specific CD4 ${ }^{+} \mathrm{T}$ cells, while in vitro blockade of PD-1 restores the proliferative nature of these cells lost after exhaustion [230]. Expression of CTLA- 4 by CD4 ${ }^{+}$T-cells was shown for HIV-1 infected patients, while in vitro blockade of CTLA-4 leads to a significant increase in proliferation [231]. Interestingly, specific IC markers on $\mathrm{CD}^{+}{ }^{+} \mathrm{T}$ cells are associated with higher levels of HIV-1 DNA, suggesting that these ICs somehow contribute to latency in these subsets [232,233].

The "shock and kill" strategy for HIV-1 consists of clearing the HIV-1 reservoir in resting $\mathrm{CD}^{+}$memory T cells [234]. During the "shock" phase, drugs called latencyreversing agents are used to reactivate viruses that persist latently in the cell due to the increase in the expression of viral gene products. In the "kill" phase the infected cells are destroyed [235]. Hypothetical treatment of HIV-1 would work in two potential ways: by enhancing the effector function of HIV-specific CD8 ${ }^{+} \mathrm{T}$ cells and reversing the HIV-1 latency period. In animal models, the introduction of IC blockade has a significant effect: for example, blockade of PD-1 leads to a rapid expansion of SIV-specific CD8 ${ }^{+} \mathrm{T}$ cells with increased functionality [236], and blockade of CTLA-4 leads to an increase in plasma viremia and activation of T cells [237]. Prevention of the inhibitory signals will lead to increased gene expression and subsequent production of viral proteins, making the cells "visible" to both the immune system and antiretroviral treatment, as well as becoming susceptible to virus-mediated cytotoxicity [238].

Anti-IC Abs expressed on infected cells can be used for blocking IC [239]. Abs against the IC molecules block their inhibitory action, preventing exhaustion of CD8 ${ }^{+} \mathrm{T}$ cells [240]. In untreated monkeys infected with SIV [236,241], administration of anti-PD-1 Abs expanded and increased the functionality of virus-specific $\mathrm{CD}^{+} \mathrm{T}$ cells, significantly reduced RNA survival in the blood plasma, prolonged survival [236], and resulted in a decrease in immune activation markers [241]. Introduction of Abs against PD-L1 reduced HIV-1 replication and increased the number of $\mathrm{CD}^{+} \mathrm{T}$ cells in untreated HIV-infected humanized mice [242].

Anti-PD-1 and anti-PD-L1 mAbs improve specific $\mathrm{CD}^{+}$responses for HIV-1 and show immune-mediated toxicity. Thus, IC blockade is a potential tool for reversing immune exhaustion and could be a component of an HIV-1 treatment strategy [239].

\section{COVID-19 and HIV-1}

There is little evidence on the contribution of HIV-1 to previous epidemics of respiratory viruses. HIV-1 is associated with a higher risk of severe respiratory infections, including seasonal influenza $[243,244]$. However, the contribution of HIV-1 infection to 
outcomes during the 2009 H1N1 influenza pandemic was unclear. There would be no substantial evidence that HIV-infected individuals were at increased risk of infection or had worse outcomes unless they were in advanced immunosuppression [245]. HIV-1 infection was not associated with increased disease severity during previous SARS and MERS outbreaks; there were only a few reports of mild illness among people living with HIV-1 [246,247].

The SARS-CoV-2 pandemic has become the greatest threat to global health in the modern era. It should be recognized that HIV-1/AIDS and COVID-19 are completely different diseases with different modes of transmission and disease course. First, HIV spreads through body fluids, while COVID-19 is currently considered an acute airborne infection [248]. People with chronic illnesses are at risk of relatively more severe COVID-19 symptoms, including those with weakened immune systems [249-251]. Therefore, HIV-1 infected patients may experience heightened feelings of anxiety about being infected with COVID-19 [248,252,253]. The US Centers for Disease Control and Prevention classifies immunocompromised people as high-risk, focusing on people living with uncontrolled HIV-1 or AIDS.

In addition to the unprecedented disruption of life, the COVID-19 pandemic has seriously hampered global HIV-1 care since the attention, resources, and personnel have been diverted to combat COVID-19 [254-256]. It is estimated that about 19\% of HIV-infected patients could not receive antiretroviral drugs due to the pandemic. In addition, there have been reports that several HIV-1/AIDS prevention and control centers around the world have been converted to COVID-19 treatment centers, making it impossible for HIV-1 patients to receive therapy [257].

Surprisingly, some studies have shown that COVID-19 pathology is not very different in HIV-infected individuals compared to the general population [258-260]. HIV-positive patients do not develop the intense immunological response that often complicates the clinical course of COVID-19 [261]. Coinfection with HIV-1 and SARS-CoV-2 does not appear to cause a difference in clinical presentation. Currently, the COVID-19 guidelines for well-controlled HIV-1 infection indicate that it is unlikely that people living with HIV-1 are at greater risk of contracting COVID-19 or more severe illness than the general population [262].

Thus, the COVID pandemic has highlighted the need to develop new HIV-1 prevention and treatment approaches. Still, the Omicron variant, originally found in Botswana and South Africa, has made an even greater contribution. It was reported to the World Health Organization on 24 November 2021 and was identified as an option of concern on 26 November 2021. This outbreak of the Omicron variant in Europe and North America has shown that efficient vaccination may be powerless against new variants of the virus evolving in immunocompromised organisms. Undoubtedly, the Omicron variant is not the last example of how HIV-infected people can become reservoirs for new forms of diseases that might be dangerous for humanity.

Most people can effectively combat SARS-CoV-2 [263,264]. However, several reports suggest that long-term coronavirus infection can persist for many months in HIV-positive patients not receiving antiretroviral therapy $[265,266]$. It has been shown that the SARS-CoV2 , evolving in the patient for a long time, replicates and undergoes mutations, especially in the S-protein. It has been hypothesized that evolution within the host may be one of the mechanisms for the emergence of SARS-CoV-2 variants $[267,268]$. Thus, the emergence of new variants of SARS-CoV-2 in some cases may be associated with mutations occurring within HIV-1 infected patients with immunosuppression, with an advanced stage of HIV-1, which cannot get rid of SARS-CoV-2 [269].

Two cases of particular interest were identified in hospitals in South Africa [269]. One issue is devoted to the HIV-infected woman (with an advanced stage of HIV-1 and failure of antiretroviral treatment) at about 30 years with persistent infection with SARSCoV-2. Despite a short clinical illness of moderate severity, a positive PCR result for SARS-CoV-2 lasted up to 216 days. Significant shifts in the viral population have been 
demonstrated during this time, including multiple mutations in key $\mathrm{nAb}$ epitopes in the RBD and N-terminal domain of spike protein [269]. In another documented case of longterm infection in an HIV-1 infected with profound immunodeficiency, genome sequencing showed only one mutation arising in the spike (T719I) at 53 days [270]. Most other cases of chronic COVID-19 infection were described in people with hematologic malignancies or people receiving immunosuppressive therapies for solid organ transplants or other chronic diseases [270,271]. Genomic and clinical data suggest that the evolution of the virus may have been triggered by selective pressure due to an impaired response of $n A b s$.

Two studies from South Africa demonstrated that HIV-1 is associated with suboptimal $\mathrm{CD}^{+} \mathrm{T}$ cells and humoral immune responses to SARS-CoV-2, especially in the absence of suppressive antiretroviral therapy [272,273]; and one US study showed that HIV-1 is associated with lower $\mathrm{nAb}$ titers after natural infection [274]. Immunosuppression due to the ineffectiveness of antiretroviral treatment and resistance to HIV-1 drugs leads to a violation of both cellular and adaptive humoral immunity, which prevents the elimination of SARS-CoV-2 [275].

South Africa has the world's most extensive HIV-1 treatment program, with about 5.2 million people in therapy. Despite this, there remains a significant number of people with progressive HIV-1 infection [276,277]. Preliminary results in patients with controlled HIV-1 indicate that the immune response to COVID-19 vaccines is equivalent to that of HIVnegative people [278]. Still, more research is needed to understand the immunogenicity and effectiveness of vaccination and develop optimal dosing strategies, especially for patients with advanced HIV-1 infection. If the persistent infection does occur more frequently in the context of HIV-1, this could warrant a preference for people living with HIV-1 to be vaccinated against COVID-19.

We believe that concerns about the potential link between the emergence of new variants of infectious diseases in people living with HIV-1 will spur more active global action to develop HIV-1 vaccines, as HIV-1 prevention in many regions is not given adequate attention and funding due to the COVID-19 pandemic.

\subsection{Immunological Features of COVID-19 in HIV-1 Infected Patients}

If untreated, HIV-1 infection leads to a decrease in the CD4 T cell count, leading to AIDS. AIDS is defined as a CD4 cell count $<200$ cells $/ \mu \mathrm{L}$ [279]. If HIV- 1 infection is controlled, the risk of serious complications from COVID-19, and therefore poor outcomes, is likely to be low. However, the same cannot be said for poorly controlled HIV-1 infection or AIDS [280].

Some immunological features are inherent in both viral infections. Changes in lymphocyte subpopulations are characteristic of patients with COVID-19: lymphocyte depletion is a sign of severe COVID-19 [281-283]. An overall decrease in lymphocyte counts, including $\mathrm{CD}^{+} \mathrm{T}$ cells, $\mathrm{CD}^{+} \mathrm{T}$ cells, B cells, and NK cells, has been observed in severe and deceased patients with COVID-19 [284,285]. The acute phase of HIV-1 infection is characterized by a significant decrease in $\mathrm{CD}^{+} \mathrm{T}$ lymphocyte counts that persisted throughout the chronic phase, resulting in the lymphopenia seen in untreated AIDS patients [286-288].

Cytokine storm in patients with COVID-19 is associated with the severity of the outcome [289-291], HIV-1 infection is associated with persistent immune system impairment, even during effective antiretroviral therapy. This dysregulation may paradoxically prevent cytokine release in severe and critical COVID-19 [292,293]. This may explain the milder symptoms, lower morbidity, and lower mortality among HIV-infected patients infected with COVID-19 since the main fatal condition in COVID patients is caused by a cytokine storm, which subsequently leads to multiple organ dysfunction and death [294]. The lack of $\mathrm{T}$ cell activation is thought to mitigate the severe immunopathological events seen in COVID-19 [295]; the effects of the antiretroviral therapy were controversial. Antiretroviral therapy was proposed to protect against SARS-CoV-1 in 2003 [296]. Several antiretrovirals, including tenofovir and lopinavir, have shown antiviral activity against SARS-CoV-2 
in vitro [297,298]. However, a randomized clinical trial of lopinavir/ritonavir showed no reduction in mortality in severe COVID-19 [299].

\subsection{SARS-CoV-2 and HIV-1 Vaccines}

Intensive research of HIV-1 and attempts to develop an HIV-1-vaccine at the end of the 20th century and of the early 21st century led to tremendous technical and scientific advances in virology, molecular immunology, and particularly vaccinology. These experimental results and clinical trials made it possible to develop effective vaccines against SARS-CoV-2 in the shortest time. Why were the SARS-CoV-2 vaccines produced so quickly, and the HIV-1 vaccine still is not yet developed? We suggest that the main difference between SARS-CoV-2 and HIV-1 is that the patients infected with SARS-CoV-2 can get rid of the virus. A double dose of vaccine stimulates a secondary immune response, which leads to the destruction of infected cells [264]. In the case of HIV-1, the virus integrates into the genome, forms a CD4 ${ }^{+} \mathrm{T}$ cell reservoir, leading to chronic infection [300]. The target of nAbs in the case of SARS-CoV-2 is the receptor-binding domain of the S-glycoprotein. Neutralizing Abs block the binding of SARS-CoV-2 virion to the Ace2-receptor [301-303]. Abs neutralizing SARS-CoV-2 are easily formed in the body after COVID-19 infection or after vaccination [304-306]; on the opposite, HIV-1 can evade immunity and possess significant genetic variation among strains. This poses serious obstacles to vaccine development; the vaccine must produce Abs that can adapt to the Env glycan screen and bind to various viral strains to provide protection $[158,159]$.

\section{Conclusions}

The highest priority in HIV-1 research remains the development of a preventive vaccine. Despite many years of attempts to develop an HIV-1 vaccine based on classical strategies, it has not been possible so far. The search for a vaccine is still ongoing. One of the main focuses of a preventive vaccine is the induction of protective immune responses in the early stages of HIV-1 infection. Among the main obstacles encountered in developing an effective vaccine are mutational variability and global viral diversity, making it easy to avoid cellular and humoral host responses. One of the goals of studying Abs in HIV-1 infection is to determine how to safely induce broadly reactive protective Abs against HIV-1. At the same time, such Abs should trigger a cascade of autoimmune reactions. Since HIV-1 is transmitted primarily through mucous membranes, understanding antiviral immunity in mucosal sites is of great importance.

The first step in developing effective vaccines is understanding HIV-1 evolutionary strategies. One of these strategies is the ability of HIV-1 to suppress the adaptive immune response to vulnerable envelope epitopes, which must be maintained in the most conservative form since they are necessary to maintain the infectivity of the virus. Because of HIV-1's ability to elude Ab responses, the vaccine must induce the production of multiple bNAbs that will target various conserved sites on the Env glycoprotein. Thus, several batches of immunogens may be required.

Various Abs against antigens were described in HIV-1, including autoAbs with catalytic activities. Biological functions of natural Abs in HIV-1 infection, and in the first place, polyreactive and autoAbs, have not been sufficiently studied. Thus, the task of analyzing natural and artificial Abs against HIV-1 in the context of developing an HIV-1 vaccine is unlikely to be completed soon. When creating a vaccine against HIV-1, it is necessary to consider the design of the immunogen and the method of its delivery, and the production of nAbs and avoid the production of harmful autoAbs. Among the priorities is the solution of the following problems: generation of bNAbs after vaccination and production of monoclonal bNAbs with broad prospects for therapeutic use.

Author Contributions: Conceptualization, S.S.; writing-original draft preparation, A.T.; writingreview and editing, S.S.; visualization, A.T.; supervision, G.N.; project administration, A.T.; funding acquisition, A.T. and S.S. All authors have read and agreed to the published version of the manuscript. 
Funding: This research was funded by RSF 21-75-10105 to Anna Timofeeva (Section 7), RFBR 2034-70115 to Sergey Sedykh (Sections 2, 3 and 5), and 0245-2021-0009 (121031300041-4) to Georgy Nevinsky (Sections 4 and 6).

Conflicts of Interest: The authors declare no conflict of interest.

\section{References}

1. Barré-Sinoussi, F.; Ross, A.L.; Delfraissy, J.-F. Past, present and future: 30 years of HIV research. Nat. Rev. Microbiol. 2013, 11, 877-883. [CrossRef] [PubMed]

2. Taylor, B.S.; Sobieszczyk, M.E.; McCutchan, F.E.; Hammer, S.M. The Challenge of HIV-1 Subtype Diversity. N. Engl. J. Med. 2008, 358, 1590-1602. [CrossRef]

3. Hemelaar, J.; Gouws, E.; Ghys, P.D.; Osmanov, S. Global and regional distribution of HIV-1 genetic subtypes and recombinants in 2004. AIDS 2006, 20, W13-W23. [CrossRef] [PubMed]

4. Korber, B.; Gaschen, B.; Yusim, K.; Thakallapally, R.; Kesmir, C.; Detours, V. Evolutionary and immunological implications of contemporary HIV-1 variation. Br. Med. Bull. 2001, 58, 19-42. [CrossRef] [PubMed]

5. Wei, X.; Decker, J.M.; Wang, S.; Hui, H.; Kappes, J.C.; Wu, X.; Salazar-Gonzalez, J.F.; Salazar, M.G.; Kilby, J.M.; Saag, M.S.; et al. Antibody neutralization and escape by HIV-1. Nature 2003, 422, 307-312. [CrossRef] [PubMed]

6. Richman, D.D.; Wrin, T.; Little, S.J.; Petropoulos, C.J. Rapid evolution of the neutralizing antibody response to HIV type 1 infection. Proc. Natl. Acad. Sci. USA 2003, 100, 4144-4149. [CrossRef]

7. Liu, J.; Bartesaghi, A.; Borgnia, M.J.; Sapiro, G.; Subramaniam, S. Molecular architecture of native HIV-1 gp120 trimers. Nature 2008, 455, 109-113. [CrossRef]

8. Kwong, P.D.; Wyatt, R.; Robinson, J.; Sweet, R.W.; Sodroski, J.; Hendrickson, W.A. Structure of an HIV gp120 envelope glycoprotein in complex with the CD4 receptor and a neutralizing human antibody. Nature 1998, 393, 648-659. [CrossRef]

9. Chen, B.; Vogan, E.M.; Gong, H.; Skehel, J.J.; Wiley, D.C.; Harrison, S.C. Structure of an unliganded simian immunodeficiency virus gp120 core. Nature 2005, 433, 834-841. [CrossRef]

10. Yu, W.-H.; Zhao, P.; Draghi, M.; Arevalo, C.; Karsten, C.B.; Suscovich, T.J.; Gunn, B.; Streeck, H.; Brass, A.L.; Tiemeyer, M.; et al. Exploiting glycan topography for computational design of Env glycoprotein antigenicity. PLoS Comput. Biol. 2018, 14, e1006093. [CrossRef]

11. Barin, F.; McLane, M.F.; Allan, J.S.; Lee, T.H.; Groopman, J.E.; Essex, M. Virus Envelope Protein of HTLV-III Represents Major Target Antigen for Antibodies in AIDS Patients. Science 1985, 228, 1094-1096. [CrossRef] [PubMed]

12. Allan, J.S.; Coligan, J.E.; Barin, F.; McLane, M.F.; Sodroski, J.G.; Rosen, C.A.; Haseltine, W.A.; Lee, T.H.; Essex, M. Major Glycoprotein Antigens That Induce Antibodies in AIDS Patients Are Encoded by HTLV-III. Science 1985, 228, 1091-1094. [CrossRef]

13. Okabe, M.; Kubara, K.; Kawaguchi, H.; Kawano, T.; Nakashima, Y.; Fukuda, K.; Hiroki, T.; Arakawa, K.; Kikuchi, M. A case of myxedema with diffuse myocardial fibrosis proven by endomyocardial biopsy. Kokyu Junkan Respir. Circ. 1990, 38, $1159-1163$.

14. Moore, J.P.; Cao, Y.; Ho, D.D.; Koup, R.A. Development of the anti-gp120 antibody response during seroconversion to human immunodeficiency virus type 1. J. Virol. 1994, 68, 5142-5155. [CrossRef] [PubMed]

15. Soudeyns, H.; Pantaleo, G. The moving target: Mechanisms of HIV persistence during primary infection. Immunol. Today 1999, 20, 446-450. [CrossRef]

16. Cao, Y.; Qin, L.; Zhang, L.; Safrit, J.; Ho, D.D. Virologic and Immunologic Characterization of Long-Term Survivors of Human Immunodeficiency Virus Type 1 Infection. N. Engl. J. Med. 1995, 332, 201-208. [CrossRef]

17. Walker, L.M.; Simek, M.D.; Priddy, F.; Gach, J.S.; Wagner, D.; Zwick, M.B.; Phogat, S.K.; Poignard, P.; Burton, D.R. A Limited Number of Antibody Specificities Mediate Broad and Potent Serum Neutralization in Selected HIV-1 Infected Individuals. PLoS Pathog. 2010, 6, e1001028. [CrossRef]

18. Doria-Rose, N.A.; Klein, R.M.; Daniels, M.G.; O’Dell, S.; Nason, M.; Lapedes, A.; Bhattacharya, T.; Migueles, S.A.; Wyatt, R.T.; Korber, B.T;; et al. Breadth of Human Immunodeficiency Virus-Specific Neutralizing Activity in Sera: Clustering Analysis and Association with Clinical Variables. J. Virol. 2010, 84, 1631-1636. [CrossRef]

19. Gray, E.S.; Madiga, M.C.; Hermanus, T.; Moore, P.L.; Wibmer, C.K.; Tumba, N.L.; Werner, L.; Mlisana, K.; Sibeko, S.; Williamson, C.; et al. The Neutralization Breadth of HIV-1 Develops Incrementally over Four Years and Is Associated with CD4 ${ }^{+} \mathrm{T}$ Cell Decline and High Viral Load during Acute Infection. J. Virol. 2011, 85, 4828-4840. [CrossRef]

20. Burton, D.R.; Desrosiers, R.C.; Doms, R.W.; Koff, W.C.; Kwong, P.D.; Moore, J.P.; Nabel, G.J.; Sodroski, J.; Wilson, I.A.; Wyatt, R.T. HIV vaccine design and the neutralizing antibody problem. Nat. Immunol. 2004, 5, 233-236. [CrossRef]

21. Kwong, P.D.; Doyle, M.L.; Casper, D.J.; Cicala, C.; Leavitt, S.A.; Majeed, S.; Steenbeke, T.D.; Venturi, M.; Chaiken, I.; Fung, M.; et al. HIV-1 evades antibody-mediated neutralization through conformational masking of receptor-binding sites. Nature 2002, 420, 678-682. [CrossRef] [PubMed]

22. Mascola, J.R.; Montefiori, D.C. HIV-1: Nature's master of disguise. Nat. Med. 2003, 9, 393-394. [CrossRef] [PubMed]

23. Kessler, J.A.; McKenna, P.M.; Emini, E.A.; Chan, C.P.; Patel, M.D.; Gupta, S.K.; Mark, G.E.; Barbas, C.F.; Burton, D.R.; Conley, A.J. Recombinant Human Monoclonal Antibody IgG1b12 Neutralizes Diverse Human Immunodeficiency Virus Type 1 Primary Isolates. AIDS Res. Hum. Retroviruses 1997, 13, 575-582. [CrossRef] [PubMed] 
24. Parren, P.W.H.I.; Wang, M.; Trkola, A.; Binley, J.M.; Purtscher, M.; Katinger, H.; Moore, J.P.; Burton, D.R. Antibody NeutralizationResistant Primary Isolates of Human Immunodeficiency Virus Type 1. J. Virol. 1998, 72, 10270-10274. [CrossRef]

25. Trkola, A.; Purtscher, M.; Muster, T.; Ballaun, C.; Buchacher, A.; Sullivan, N.; Srinivasan, K.; Sodroski, J.; Moore, J.P.; Katinger, H Human monoclonal antibody 2G12 defines a distinctive neutralization epitope on the gp120 glycoprotein of human immunodeficiency virus type 1. J. Virol. 1996, 70, 1100-1108. [CrossRef]

26. Zwick, M.B.; Labrijn, A.F.; Wang, M.; Spenlehauer, C.; Saphire, E.O.; Binley, J.M.; Moore, J.P.; Stiegler, G.; Katinger, H.; Burton, D.R.; et al. Broadly Neutralizing Antibodies Targeted to the Membrane-Proximal External Region of Human Immunodeficiency Virus Type 1 Glycoprotein gp41. J. Virol. 2001, 75, 10892-10905. [CrossRef]

27. Muster, T.; Steindl, F.; Purtscher, M.; Trkola, A.; Klima, A.; Himmler, G.; Rüker, F.; Katinger, H. A conserved neutralizing epitope on gp41 of human immunodeficiency virus type 1. J. Virol. 1993, 67, 6642-6647. [CrossRef]

28. Wu, X.; Yang, Z.-Y.; Li, Y.; Hogerkorp, C.-M.; Schief, W.R.; Seaman, M.S.; Zhou, T.; Schmidt, S.D.; Wu, L.; Xu, L.; et al. Rational design of envelope identifies broadly neutralizing human monoclonal antibodies to HIV-1. Science 2010, 329, 856-861. [CrossRef]

29. Conley, A.J.; Gorny, M.K.; Kessler, J.A.; Boots, L.J.; Ossorio-Castro, M.; Koenig, S.; Lineberger, D.W.; Emini, E.A.; Williams, C.; Zolla-Pazner, S. Neutralization of primary human immunodeficiency virus type 1 isolates by the broadly reactive anti-V3 monoclonal antibody, 447-452D. J. Virol. 1994, 68, 6994-7000. [CrossRef]

30. Burton, D.R.; Pyati, J.; Koduri, R.; Sharp, S.J.; Thornton, G.B.; Parren, P.W.H.I.; Sawyer, L.S.W.; Hendry, R.M.; Dunlop, N.; Nara, P.L.; et al. Efficient Neutralization of Primary Isolates of HIV-1 by a Recombinant Human Monoclonal Antibody. Science 1994, 266, 1024-1027. [CrossRef]

31. Binley, J.M.; Wrin, T.; Korber, B.; Zwick, M.B.; Wang, M.; Chappey, C.; Stiegler, G.; Kunert, R.; Zolla-Pazner, S.; Katinger, H.; et al Comprehensive Cross-Clade Neutralization Analysis of a Panel of Anti-Human Immunodeficiency Virus Type 1 Monoclonal Antibodies. J. Virol. 2004, 78, 13232-13252. [CrossRef] [PubMed]

32. Walker, L.M.; Phogat, S.K.; Chan-Hui, P.-Y.; Wagner, D.; Phung, P.; Goss, J.L.; Wrin, T.; Simek, M.D.; Fling, S.; Mitcham, J.L.; et al. Broad and Potent Neutralizing Antibodies from an African Donor Reveal a New HIV-1 Vaccine Target. Science 2009, 326, $285-289$. [CrossRef] [PubMed]

33. Corti, D.; Langedijk, J.P.M.; Hinz, A.; Seaman, M.S.; Vanzetta, F.; Fernandez-Rodriguez, B.M.; Silacci, C.; Pinna, D.; Jarrossay, D.; Balla-Jhagihoorsingh, S.; et al. Analysis of Memory B Cell Responses and Isolation of Novel Monoclonal Antibodies with Neutralizing Breadth from HIV-1-Infected Individuals. PLoS ONE 2010, 5, e8805. [CrossRef]

34. Zhou, T.; Xu, L.; Dey, B.; Hessell, A.J.; Van Ryk, D.; Xiang, S.-H.; Yang, X.; Zhang, M.-Y.; Zwick, M.B.; Arthos, J.; et al. Structural definition of a conserved neutralization epitope on HIV-1 gp120. Nature 2007, 445, 732-737. [CrossRef]

35. Morrow, W.J.W.; Isenberg, D.A.; Sobol, R.E.; Stricker, R.B.; Kieber-Emmons, T. AIDS virus infection and autoimmunity: A perspective of the clinical, immunological, and molecular origins of the autoallergic pathologies associated with HIV disease. Clin. Immunol. Immunopathol. 1991, 58, 163-180. [CrossRef]

36. González, C.M.; López-LONGO, F.J.; Samson, J.; Monteagudo, I.; Grau, R.; Rodríguez-Mahou, M.; ST-Cyr, C.; Lapointe, N.; Carreño, L. Antiribonucleoprotein Antibodies in Children with HIV Infection: A Comparative Study with Childhood-Onset Systemic Lupus Erythematosus. AIDS Patient Care STDS 1998, 12, 21-28. [CrossRef] [PubMed]

37. Argov, S.; Schattner, A.; Burstein, R.; Handzel, Z.T.; Shoenfeld, Y.; Bentwich, Z. Autoantibodies in male homosexuals and HIV infection. Immunol. Lett. 1991, 30, 31-35. [CrossRef]

38. Zandman-Goddard, G.; Shoenfeld, Y. HIV and autoimmunity. Autoimmun. Rev. 2002, 1, 329-337. [CrossRef]

39. Sizyakina, L.P.; Buneva, V.N.; Nevinsky, G.A.; Odintsova, E.S.; Kharitonova, M.A.; Baranovskii, A.G.; Sizyakina, L.P.; Buneva, V.N.; Nevinsky, G.A. Proteolytic activity of IgG antibodies from blood of acquired immunodeficiency syndrome patients. Biochemistry 2006, 71, 251-261. [CrossRef]

40. Baranova, S.V.; Buneva, V.N.; Nevinsky, G.A. Antibodies from the sera of HIV-infected patients efficiently hydrolyze all human histones. J. Mol. Recognit. 2016, 29, 346-362. [CrossRef]

41. Baranova, S.V.; Dmitrienok, P.S.; Buneva, V.N.; Nevinsky, G.A. Autoantibodies in HIV-infected patients: Cross site-specific hydrolysis of H1 histone and myelin basic protein. BioFactors 2019, 45, 211-222. [CrossRef] [PubMed]

42. Baranova, S.V.; Buneva, V.N.; Kharitonova, M.A.; Sizyakina, L.P.; Calmels, C.; Andreola, M.-L.; Parissi, V.; Nevinsky, G. HIV-1 integrase-hydrolyzing antibodies from sera of HIV-infected patients. Biochimie 2009, 91, 1081-1086. [CrossRef] [PubMed]

43. Baranova, S.V.; Buneva, V.N.; Kharitonova, M.A.; Sizyakina, L.P.; Calmels, C.; Andreola, M.-L.M.-L.; Parissi, V.; Zakharova, O.D.; Nevinsky, G.A. HIV-1 integrase-hydrolyzing IgM antibodies from sera of HIV-infected patients. Int. Immunol. 2010, 22, 671-680. [CrossRef] [PubMed]

44. Miedema, F. A brief history of HIV vaccine research: Stepping back to the drawing board? AIDS 2008, 22, 1699-1703. [CrossRef]

45. Pitisuttithum, P.; Gilbert, P.; Gurwith, M.; Heyward, W.; Martin, M.; van Griensven, F.; Hu, D.; Tappero, J.W. Bangkok Vaccine Evaluation Group Randomized, Double-Blind, Placebo-Controlled Efficacy Trial of a Bivalent Recombinant Glycoprotein 120 HIV-1 Vaccine among Injection Drug Users in Bangkok, Thailand. J. Infect. Dis. 2006, 194, 1661-1671. [CrossRef]

46. Sekaly, R.-P. The failed HIV Merck vaccine study: A step back or a launching point for future vaccine development? J. Exp. Med. 2008, 205, 7-12. [CrossRef]

47. Rerks-Ngarm, S.; Pitisuttithum, P.; Nitayaphan, S.; Kaewkungwal, J.; Chiu, J.; Paris, R.; Premsri, N.; Namwat, C.; de Souza, M.; Adams, E.; et al. Vaccination with ALVAC and AIDSVAX to Prevent HIV-1 Infection in Thailand. N. Engl. J. Med. 2009, 361, 2209-2220. [CrossRef] 
48. Paul, S.; Planque, S.; Nishiyama, Y.; Escobar, M.; Hanson, C. Back to the future: Covalent epitope-based HIV vaccine development. Expert Rev. Vaccines 2010, 9, 1027-1043. [CrossRef]

49. Spencer, D.A.; Shapiro, M.B.; Haigwood, N.L.; Hessell, A.J. Advancing HIV Broadly Neutralizing Antibodies: From Discovery to the Clinic. Front. Public Health 2021, 9, 610. [CrossRef]

50. Williams, W.B.; Wiehe, K.; Saunders, K.O.; Haynes, B.F. Strategies for induction of HIV-1 envelope-reactive broadly neutralizing antibodies. J. Int. AIDS Soc. 2021, 24, e25831. [CrossRef]

51. Verkoczy, L.; Alt, F.W.; Tian, M. Human Ig knockin mice to study the development and regulation of HIV-1 broadly neutralizing antibodies. Immunol. Rev. 2017, 275, 89-107. [CrossRef] [PubMed]

52. Stamatatos, L.; Pancera, M.; McGuire, A.T. Germline-targeting immunogens. Immunol. Rev. 2017, 275, 203-216. [CrossRef] [PubMed]

53. Huang, D.; Tran, J.T.; Olson, A.; Vollbrecht, T.; Tenuta, M.; Guryleva, M.V.; Fuller, R.P.; Schiffner, T.; Abadejos, J.R.; Couvrette, L.; et al. Vaccine elicitation of HIV broadly neutralizing antibodies from engineered B cells. Nat. Commun. 2020, 11, 5850. [CrossRef] [PubMed]

54. Fauci, A.S.; Marston, H.D. Toward an HIV vaccine: A scientific journey. Science 2015, 349, 386-387. [CrossRef]

55. Mascola, J.R.; Montefiori, D.C. The Role of Antibodies in HIV Vaccines. Annu. Rev. Immunol. 2010, 28, 413-444. [CrossRef]

56. Pantophlet, R.; Burton, D.R. GP120: Target for Neutralizing HIV-1 Antibodies. Annu. Rev. Immunol. 2006, 24, 739-769. [CrossRef]

57. Montefiori, D.C.; Morris, L.; Ferrari, G.; Mascola, J.R. Neutralizing and other antiviral antibodies in HIV-1 infection and vaccination. Curr. Opin. HIV AIDS 2007, 2, 169-176. [CrossRef]

58. Cheng-Mayer, C.; Homsy, J.; Evans, L.A.; Levy, J.A. Identification of human immunodeficiency virus subtypes with distinct patterns of sensitivity to serum neutralization. Proc. Natl. Acad. Sci. USA 1988, 85, 2815-2819. [CrossRef]

59. Brown, B.K.; Wieczorek, L.; Sanders-Buell, E.; Borges, A.R.; Robb, M.L.; Birx, D.L.; Michael, N.L.; McCutchan, F.E.; Polonis, V.R. Cross-clade neutralization patterns among HIV-1 strains from the six major clades of the pandemic evaluated and compared in two different models. Virology 2008, 375, 529-538. [CrossRef]

60. Kostrikis, L.G.; Cao, Y.; Ngai, H.; Moore, J.P.; Ho, D.D. Quantitative analysis of serum neutralization of human immunodeficiency virus type 1 from subtypes A, B, C, D, E, F, and I: Lack of direct correlation between neutralization serotypes and genetic subtypes and evidence for prevalent serum-dependent infecti. J. Virol. 1996, 70, 445-458. [CrossRef]

61. Haynes, B.F.; Burton, D.R.; Mascola, J.R. Multiple roles for HIV broadly neutralizing antibodies. Sci. Transl. Med. 2019, 11, eaaz2686. [CrossRef] [PubMed]

62. Burton, D.R.; Hangartner, L. Broadly Neutralizing Antibodies to HIV and Their Role in Vaccine Design. Anmu. Rev. Immunol. 2016, 34, 635-659. [CrossRef] [PubMed]

63. Stamatatos, L.; Morris, L.; Burton, D.R.; Mascola, J.R. Neutralizing antibodies generated during natural HIV-1 infection: Good news for an HIV-1 vaccine? Nat. Med. 2009, 15, 866-870. [CrossRef] [PubMed]

64. Sather, D.N.; Armann, J.; Ching, L.K.; Mavrantoni, A.; Sellhorn, G.; Caldwell, Z.; Yu, X.; Wood, B.; Self, S.; Kalams, S.; et al. Factors Associated with the Development of Cross-Reactive Neutralizing Antibodies during Human Immunodeficiency Virus Type 1 Infection. J. Virol. 2009, 83, 757-769. [CrossRef]

65. Simek, M.D.; Rida, W.; Priddy, F.H.; Pung, P.; Carrow, E.; Laufer, D.S.; Lehrman, J.K.; Boaz, M.; Tarragona-Fiol, T.; Miiro, G.; et al Human Immunodeficiency Virus Type 1 Elite Neutralizers: Individuals with Broad and Potent Neutralizing Activity Identified by Using a High-Throughput Neutralization Assay together with an Analytical Selection Algorithm. J. Virol. 2009, 83, 7337-7348. [CrossRef]

66. Doria-Rose, N.A.; Klein, R.M.; Manion, M.M.; O’Dell, S.; Phogat, A.; Chakrabarti, B.; Hallahan, C.W.; Migueles, S.A.; Wrammert, J.; Ahmed, R.; et al. Frequency and Phenotype of Human Immunodeficiency Virus Envelope-Specific B Cells from Patients with Broadly Cross-Neutralizing Antibodies. J. Virol. 2009, 83, 188-199. [CrossRef]

67. Montefiori, D.; Sattentau, Q.; Flores, J.; Esparza, J.; Mascola, J. Antibody-Based HIV-1 Vaccines: Recent Developments and Future Directions. PLoS Med. 2007, 4, e348. [CrossRef]

68. Karsten, C.B.; Alter, G. The HIV-1 Glycan Shield: Strategically Placed Kinks in the Armor Improve Antigen Design. Cell Rep. 2017, 19, 669-670. [CrossRef]

69. Cohen, Y.Z.; Lavine, C.L.; Miller, C.A.; Garrity, J.; Carey, B.R.; Seaman, M.S. Glycan-Dependent Neutralizing Antibodies Are Frequently Elicited in Individuals Chronically Infected with HIV-1 Clade B or C. AIDS Res. Hum. Retroviruses 2015, 31, $1192-1201$. [CrossRef]

70. Gray, E.S.; Moore, P.L.; Choge, I.A.; Decker, J.M.; Bibollet-Ruche, F.; Li, H.; Leseka, N.; Treurnicht, F.; Mlisana, K.; Shaw, G.M.; et al. Neutralizing Antibody Responses in Acute Human Immunodeficiency Virus Type 1 Subtype C Infection. J. Virol. 2007, 81, 6187-6196. [CrossRef]

71. Tomaras, G.D.; Yates, N.L.; Liu, P.; Qin, L.; Fouda, G.G.; Chavez, L.L.; Decamp, A.C.; Parks, R.J.; Ashley, V.C.; Lucas, J.T.; et al. Initial B-Cell Responses to Transmitted Human Immunodeficiency Virus Type 1: Virion-Binding Immunoglobulin M (IgM) and IgG Antibodies Followed by Plasma Anti-gp41 Antibodies with Ineffective Control of Initial Viremia. J. Virol. 2008, 82, 12449-12463. [CrossRef] [PubMed]

72. Li, B.; Decker, J.M.; Johnson, R.W.; Bibollet-Ruche, F.; Wei, X.; Mulenga, J.; Allen, S.; Hunter, E.; Hahn, B.H.; Shaw, G.M.; et al. Evidence for Potent Autologous Neutralizing Antibody Titers and Compact Envelopes in Early Infection with Subtype C Human Immunodeficiency Virus Type 1. J. Virol. 2006, 80, 5211-5218. [CrossRef] [PubMed] 
73. Moore, P.L.; Gray, E.S.; Choge, I.A.; Ranchobe, N.; Mlisana, K.; Abdool Karim, S.S.; Williamson, C.; Morris, L. The C3-V4 Region Is a Major Target of Autologous Neutralizing Antibodies in Human Immunodeficiency Virus Type 1 Subtype C Infection. J. Virol. 2008, 82, 1860-1869. [CrossRef] [PubMed]

74. Euler, Z.; van Gils, M.J.; Bunnik, E.M.; Phung, P.; Schweighardt, B.; Wrin, T.; Schuitemaker, H. Cross-Reactive Neutralizing Humoral Immunity Does Not Protect from HIV Type 1 Disease Progression. J. Infect. Dis. 2010, 201, 1045-1053. [CrossRef]

75. Mikell, I.; Sather, D.N.; Kalams, S.A.; Altfeld, M.; Alter, G.; Stamatatos, L. Characteristics of the Earliest Cross-Neutralizing Antibody Response to HIV-1. PLoS Pathog. 2011, 7, e1001251. [CrossRef]

76. Torán, J.L.; Kremer, L.; Sánchez-Pulido, L.; de Alborán, I.M.; del Real, G.; Llorente, M.; Valencia, A.; de Mon, M.A.; Martínez, A.C. Molecular analysis of HIV-1 gp120 antibody response using isotype IgM and IgG phage display libraries from a long-term non-progressor HIV-1-infected individual. Eur. J. Immunol. 1999, 29, 2666-2675. [CrossRef]

77. Pancera, M.; McLellan, J.S.; Wu, X.; Zhu, J.; Changela, A.; Schmidt, S.D.; Yang, Y.; Zhou, T.; Phogat, S.; Mascola, J.R.; et al. Crystal Structure of PG16 and Chimeric Dissection with Somatically Related PG9: Structure-Function Analysis of Two Quaternary-Specific Antibodies That Effectively Neutralize HIV-1. J. Virol. 2010, 84, 8098-8110. [CrossRef]

78. Zhou, T.; Georgiev, I.; Wu, X.; Yang, Z.-Y.; Dai, K.; Finzi, A.; Do Kwon, Y.; Scheid, J.F.; Shi, W.; Xu, L.; et al. Structural Basis for Broad and Potent Neutralization of HIV-1 by Antibody VRC01. Science 2010, 329, 811-817. [CrossRef]

79. Moir, S.; Fauci, A.S. B cells in HIV infection and disease. Nat. Rev. Immunol. 2009, 9, 235-245. [CrossRef]

80. van Gils, M.J.; Bunnik, E.M.; Burger, J.A.; Jacob, Y.; Schweighardt, B.; Wrin, T.; Schuitemaker, H. Rapid Escape from Preserved Cross-Reactive Neutralizing Humoral Immunity without Loss of Viral Fitness in HIV-1-Infected Progressors and Long-Term Nonprogressors. J. Virol. 2010, 84, 3576-3585. [CrossRef]

81. Haynes, B.F.; Montefiori, D.C. Aiming to induce broadly reactive neutralizing antibody responses with HIV-1 vaccine candidates Expert Rev. Vaccines 2006, 5, 579-595. [CrossRef] [PubMed]

82. Letvin, N.L. Progress and obstacles in the development of an AIDS vaccine. Nat. Rev. Immunol. 2006, 6, 930-939. [CrossRef] [PubMed]

83. Barouch, D.H. Challenges in the development of an HIV-1 vaccine. Nature 2008, 455, 613-619. [CrossRef] [PubMed]

84. Binley, J. Specificities of broadly neutralizing anti-HIV-1 sera. Curr. Opin. HIV AIDS 2009, 4, 364-372. [CrossRef]

85. Gray, E.S.; Taylor, N.; Wycuff, D.; Moore, P.L.; Tomaras, G.D.; Wibmer, C.K.; Puren, A.; DeCamp, A.; Gilbert, P.B.; Wood, B.; et al. Antibody Specificities Associated with Neutralization Breadth in Plasma from Human Immunodeficiency Virus Type 1 Subtype C-Infected Blood Donors. J. Virol. 2009, 83, 8925-8937. [CrossRef]

86. Li, Y.; Svehla, K.; Louder, M.K.; Wycuff, D.; Phogat, S.; Tang, M.; Migueles, S.A.; Wu, X.; Phogat, A.; Shaw, G.M.; et al. Analysis of Neutralization Specificities in Polyclonal Sera Derived from Human Immunodeficiency Virus Type 1-Infected Individuals. J. Virol. 2009, 83, 1045-1059. [CrossRef]

87. Gray, E.S.; Madiga, M.C.; Moore, P.L.; Mlisana, K.; Abdool Karim, S.S.; Binley, J.M.; Shaw, G.M.; Mascola, J.R.; Morris, L. Broad Neutralization of Human Immunodeficiency Virus Type 1 Mediated by Plasma Antibodies against the gp41 Membrane Proximal External Region. J. Virol. 2009, 83, 11265-11274. [CrossRef]

88. Sather, D.N.; Stamatatos, L. Epitope specificities of broadly neutralizing plasmas from HIV-1 infected subjects. Vaccine 2010, 28 , B8-B12. [CrossRef] [PubMed]

89. Moore, P.L.; Gray, E.S.; Sheward, D.; Madiga, M.; Ranchobe, N.; Lai, Z.; Honnen, W.J.; Nonyane, M.; Tumba, N.; Hermanus, T.; et al. Potent and Broad Neutralization of HIV-1 Subtype C by Plasma Antibodies Targeting a Quaternary Epitope Including Residues in the V2 Loop. J. Virol. 2011, 85, 3128-3141. [CrossRef]

90. Wyatt, R.; Kwong, P.D.; Desjardins, E.; Sweet, R.W.; Robinson, J.; Hendrickson, W.A.; Sodroski, J.G. The antigenic structure of the HIV gp120 envelope glycoprotein. Nature 1998, 393, 705-711. [CrossRef]

91. Binley, J.M.; Lybarger, E.A.; Crooks, E.T.; Seaman, M.S.; Gray, E.; Davis, K.L.; Decker, J.M.; Wycuff, D.; Harris, L.; Hawkins, N.; et al. Profiling the Specificity of Neutralizing Antibodies in a Large Panel of Plasmas from Patients Chronically Infected with Human Immunodeficiency Virus Type 1 Subtypes B and C. J. Virol. 2008, 82, 11651-11668. [CrossRef] [PubMed]

92. Decker, J.M.; Bibollet-Ruche, F.; Wei, X.; Wang, S.; Levy, D.N.; Wang, W.; Delaporte, E.; Peeters, M.; Derdeyn, C.A.; Allen, S.; et al. Antigenic conservation and immunogenicity of the HIV coreceptor binding site. J. Exp. Med. 2005, 201, 1407-1419. [CrossRef] [PubMed]

93. Labrijn, A.F.; Poignard, P.; Raja, A.; Zwick, M.B.; Delgado, K.; Franti, M.; Binley, J.; Vivona, V.; Grundner, C.; Huang, C.-C.; et al. Access of Antibody Molecules to the Conserved Coreceptor Binding Site on Glycoprotein gp120 Is Sterically Restricted on Primary Human Immunodeficiency Virus Type 1. J. Virol. 2003, 77, 10557-10565. [CrossRef] [PubMed]

94. Haynes, B.F.; Fleming, J.; St Clair, E.W.; Katinger, H.; Stiegler, G.; Kunert, R.; Robinson, J.; Scearce, R.M.; Plonk, K.; Staats, H.F.; et al. Cardiolipin polyspecific autoreactivity in two broadly neutralizing HIV-1 antibodies. Science 2005, 308, 1906-1908. [CrossRef] [PubMed]

95. Rong, R.; Bibollet-Ruche, F.; Mulenga, J.; Allen, S.; Blackwell, J.L.; Derdeyn, C.A. Role of V1V2 and Other Human Immunodeficiency Virus Type 1 Envelope Domains in Resistance to Autologous Neutralization during Clade C Infection. J. Virol. 2007, 81, 1350-1359. [CrossRef]

96. Krachmarov, C.; Pinter, A.; Honnen, W.J.; Gorny, M.K.; Nyambi, P.N.; Zolla-Pazner, S.; Kayman, S.C. Antibodies That Are Cross-Reactive for Human Immunodeficiency Virus Type 1 Clade A and Clade B V3 Domains Are Common in Patient Sera from Cameroon, but Their Neutralization Activity Is Usually Restricted by Epitope Masking. J. Virol. 2005, 79, 780-790. [CrossRef] 
97. Krachmarov, C.P.; Honnen, W.J.; Kayman, S.C.; Gorny, M.K.; Zolla-Pazner, S.; Pinter, A. Factors Determining the Breadth and Potency of Neutralization by V3-Specific Human Monoclonal Antibodies Derived from Subjects Infected with Clade A or Clade B Strains of Human Immunodeficiency Virus Type 1. J. Virol. 2006, 80, 7127-7135. [CrossRef]

98. Gaschen, B.; Taylor, J.; Yusim, K.; Foley, B.; Gao, F.; Lang, D.; Novitsky, V.; Haynes, B.; Hahn, B.H.; Bhattacharya, T.; et al. Diversity Considerations in HIV-1 Vaccine Selection. Science 2002, 296, 2354-2360. [CrossRef]

99. Li, M.; Gao, F.; Mascola, J.R.; Stamatatos, L.; Polonis, V.R.; Koutsoukos, M.; Voss, G.; Goepfert, P.; Gilbert, P.; Greene, K.M.; et al. Human Immunodeficiency Virus Type 1 env Clones from Acute and Early Subtype B Infections for Standardized Assessments of Vaccine-Elicited Neutralizing Antibodies. J. Virol. 2005, 79, 10108-10125. [CrossRef]

100. Hartley, O.; Klasse, P.J.; Sattentau, Q.J.; Moore, J.P. V3: HIV's Switch-Hitter. AIDS Res. Hum. Retroviruses 2005, 21, 171-189. [CrossRef]

101. Pinter, A.; Honnen, W.J.; He, Y.; Gorny, M.K.; Zolla-Pazner, S.; Kayman, S.C. The V1/V2 Domain of gp120 Is a Global Regulator of the Sensitivity of Primary Human Immunodeficiency Virus Type 1 Isolates to Neutralization by Antibodies Commonly Induced upon Infection. J. Virol. 2004, 78, 5205-5215. [CrossRef] [PubMed]

102. Kinsey, N.E.; Anderson, M.G.; Unangst, T.J.; Joag, S.V.; Narayan, O.; Zink, M.C.; Clements, J.E. Antigenic Variation of SIV: Mutations in V4 Alter the Neutralization Profile. Virology 1996, 221, 14-21. [CrossRef]

103. Teeraputon, S.; Louisirirojchanakul, S.; Auewarakul, P. N-Linked Glycosylation in C2 Region of HIV-1 Envelope Reduces Sensitivity to Neutralizing Antibodies. Viral Immunol. 2005, 18, 343-353. [CrossRef]

104. Fauci, A.S. Multifactorial Nature of Human Immunodeficiency Virus Disease: Implications for Therapy. Science 1993, 262, 1011-1018. [CrossRef]

105. Tomar, R.H.; John, P.A.; Hennig, A.K.; Kloster, B. Cellular targets of antilymphocyte antibodies in AIDS and LAS. Clin. Immunol. Immunopathol. 1985, 37, 37-47. [CrossRef]

106. Tausk, F.A.; McCutchan, A.; Spechko, P.; Schreiber, R.D.; Gigli, I. Altered erythrocyte C3b receptor expression, immune complexes, and complement activation in homosexual men in varying risk groups for acquired immune deficiency syndrome. J. Clin. Investig. 1986, 78, 977-982. [CrossRef]

107. Ameglio, F.; Dolei, A.; Benedetto, A.; Sorrentino, R.; Tanigaki, N.; Tosi, R. Antibodies Reactive with Nonpolymorphic Epitopes on HLA Molecules Interfere in Screening Tests for the Human Immunodeficiency Virus. J. Infect. Dis. 1987, 156, 1034-1035. [CrossRef] [PubMed]

108. Morris, L.; Distenfeld, A.; Amorosi, E.; Karpatkin, S. Autoimmune Thrombocytopenic Purpura in Homosexual Men. Ann. Intern. Med. 1982, 96, 714-717. [CrossRef] [PubMed]

109. Stricker, R.B.; Abrams, D.I.; Corash, L.; Shuman, M.A. Target Platelet Antigen in Homosexual Men with Immune Thrombocytopenia. N. Engl. J. Med. 1985, 313, 1375-1380. [CrossRef]

110. Kiprov, D.; Pfaeffl, W.; Parry, G.; Lippert, R.; Lang, W.; Miller, R. Antibody-mediated peripheral neuropathies associated with ARC and AIDS: Successful treatment with plasmapheresis. J. Clin. Apher. 1988, 4, 3-7. [CrossRef]

111. de La Monte, S.M.; Gabuzda, D.H.; Ho, D.D.; Brown, R.H.; Hedley-Whyte, E.T.; Schooley, R.T.; Hirsch, M.S.; Bhan, A.K. Peripheral neuropathy in the acquired immunodeficiency syndrome. Ann. Neurol. 1988, 23, 485-492. [CrossRef] [PubMed]

112. De Angelis, V.; Biasinutto, C.; Pradella, P.; Vaccher, E.; Spina, M.; Tirelli, U. Clinical significance of positive direct antiglobulin test in patients with HIV infection. Infection 1994, 22, 92-95. [CrossRef] [PubMed]

113. Lai, M.; Visconti, E.; D'Onofrio, G.; Tamburrini, E.; Cauda, R.; Leone, G. Lower hemoglobin levels in human immunodeficiency virus-infected patients with a positive direct antiglobulin test (DAT): Relationship with DAT strength and clinical stages. Transfusion 2006, 46, 1237-1243. [CrossRef] [PubMed]

114. Yen, Y.-F.; Lan, Y.-C.; Huang, C.-T.; Jen, I.-A.; Chen, M.; Lee, C.-Y.; Chuang, P.-H.; Lee, Y.; Morisky, D.E.; Chen, Y.-M.A. Human Immunodeficiency Virus Infection Increases the Risk of Incident Autoimmune Hemolytic Anemia: A Population-Based Cohort Study in Taiwan. J. Infect. Dis. 2017, 216, 1000-1007. [CrossRef] [PubMed]

115. Yen, Y.-F.; Chuang, P.-H.; Jen, I.-A.; Chen, M.; Lan, Y.-C.; Liu, Y.-L.; Lee, Y.; Chen, Y.-H.; Chen, Y.-M.A. Incidence of autoimmune diseases in a nationwide HIV/AIDS patient cohort in Taiwan, 2000-2012. Ann. Rheum. Dis. 2017, 76, 661-665. [CrossRef] [PubMed]

116. Schved, J.F.; Dupuy-Fons, C.; Biron, C.; Quéré, I.; Janbon, C. A Prospective Epidemiological Study on the Occurrence of Antiphospholipid Antibody: The Montpellier Antiphospholipid (MAP) Study. Pathophysiol. Haemost. Thromb. 1994, $24,175-182$. [CrossRef]

117. Silvestris, F.; Frassanito, M.; Cafforio, P.; Potenza, D.; Di Loreto, M.; Tucci, M.; Grizzuti, M.; Nico, B.; Dammacco, F. Antiphosphatidylserine antibodies in human immunodeficiency virus-1 patients with evidence of T-cell apoptosis and mediate antibodydependent cellular cytotoxicity [see comments]. Blood 1996, 87, 5185-5195. [CrossRef]

118. Girón-González, J.A.; García del Río, E.; Rodríguez, C.; Rodríguez-Martorell, J.; Serrano, A. Antiphospholipid syndrome and asymptomatic carriers of antiphospholipid antibody: Prospective analysis of 404 individuals. J. Rheumatol. 2004, 31, $1560-1567$.

119. Calabrese, L.H.; Kirchner, E.; Shrestha, R. Rheumatic Complications of Human Immunodeficiency Virus Infection in the Era of Highly Active Antiretroviral Therapy: Emergence of a New Syndrome of Immune Reconstitution and Changing Patterns of Disease. Semin. Arthritis Rheum. 2005, 35, 166-174. [CrossRef]

120. Reveille, J.D. The changing spectrum of rheumatic disease in human immunodeficiency virus infection. Semin. Arthritis Rheum. 2000, 30, 147-166. [CrossRef] 
121. Mouquet, H.; Scheid, J.F.; Zoller, M.J.; Krogsgaard, M.; Ott, R.G.; Shukair, S.; Artyomov, M.N.; Pietzsch, J.; Connors, M.; Pereyra, F.; et al. Polyreactivity increases the apparent affinity of anti-HIV antibodies by heteroligation. Nature 2010, 467, 591-595. [CrossRef] [PubMed]

122. Liao, H.; Zhang, Z. Polyreactive antibodies in anti-HIV-1 responses. Curr. Mol. Med. 2018, 18, 126-133. [CrossRef] [PubMed]

123. Kobie, J.J.; Alcena, D.C.; Zheng, B.; Bryk, P.; Mattiacio, J.L.; Brewer, M.; LaBranche, C.; Young, F.M.; Dewhurst, S.; Montefiori, D.C.; et al. 9G4 Autoreactivity Is Increased in HIV-Infected Patients and Correlates with HIV Broadly Neutralizing Serum Activity. PLoS ONE 2012, 7, e35356. [CrossRef] [PubMed]

124. Jia, M.; Liberatore, R.A.; Guo, Y.; Chan, K.-W.; Pan, R.; Lu, H.; Waltari, E.; Mittler, E.; Chandran, K.; Finzi, A.; et al. VSV-Displayed HIV-1 Envelope Identifies Broadly Neutralizing Antibodies Class-Switched to IgG and IgA. Cell Host Microbe 2020, 27, 963-975.e5. [CrossRef]

125. Cizmeci, D.; Lofano, G.; Rossignol, E.; Dugast, A.-S.; Kim, D.; Cavet, G.; Nguyen, N.; Tan, Y.C.; Seaman, M.S.; Alter, G.; et al Distinct clonal evolution of B-cells in HIV controllers with neutralizing antibody breadth. Elife 2021, 10, e62648. [CrossRef]

126. Ternynck, T.; Falanga, P.B.; Unterklrscher, C.; Gregolre, J.; da Silva, L.P.; Avrameas, S. Induction of high levels of IgG autoantibodies in mice infected with Plasmodium chabaudi. Int. Immunol. 1991, 3, 29-37. [CrossRef]

127. Hentati, B.; Sato, M.N.; Payelle-Brogard, B.; Avrameas, S.; Ternynck, T. Beneficial effect of polyclonal immunoglobulins from malaria-infected BALB/c mice on the lupus-like syndrome of (NZB $\times$ NZW)F1 mice. Eur. J. Immunol. 1994, 24, 8-15. [CrossRef]

128. Barzilai, O.; Ram, M.; Shoenfeld, Y. Viral infection can induce the production of autoantibodies. Curr. Opin. Rheumatol. 2007, 19, 636-643. [CrossRef]

129. Odintsova, E.S.; Kharitonova, M.A.; Baranovskii, A.G.; Sizyakina, L.P.; Buneva, V.N.; Nevinsky, G.A. DNA-hydrolyzing IgG antibodies from the blood of patients with acquired immune deficiency syndrome. Mol. Biol. 2006, 40, 770-777. [CrossRef]

130. Baranova, S.V.; Dmitrienok, P.S.; Ivanisenko, N.V.; Buneva, V.N.; Nevinsky, G.A. Antibodies to H1 histone from the sera of HIV-infected patients recognize and catalyze site-specific degradation of this histone. J. Mol. Recognit. 2017, 30, e2588. [CrossRef]

131. Baranova, S.V.; Dmitrienok, P.S.; Ivanisenko, N.V.; Buneva, V.N.; Nevinsky, G.A. Antibodies to H2a and H2b histones from the sera of HIV-infected patients catalyze site-specific degradation of these histones. Mol. Biosyst. 2017, 13, 1090-1101. [CrossRef] [PubMed]

132. Baranova, S.V.; Dmitrenok, P.S.; Zubkova, A.D.; Ivanisenko, N.V.; Odintsova, E.S.; Buneva, V.N.; Nevinsky, G.A. Antibodies against $\mathrm{H} 3$ and $\mathrm{H} 4$ histones from the sera of HIV-infected patients catalyze site-specific degradation of these histones. J. Mol. Recognit. 2018, 31, e2703. [CrossRef] [PubMed]

133. Odintsova, E.S.; Baranova, S.V.; Dmitrenok, P.S.; Rasskazov, V.A.; Calmels, C.; Parissi, V.; Andreola, M.-L.M.-L.; Buneva, V.N.; Zakharova, O.D.; Nevinsky, G.A. Antibodies to HIV integrase catalyze site-specific degradation of their antigen. Int. Immunol. 2011, 23, 601-612. [CrossRef]

134. Odintsova, E.S.; Baranova, S.V.; Dmitrenok, P.S.; Calmels, C.; Parissi, V.; Andreola, M.-L.; Buneva, V.N.; Nevinsky, G.A. Antiintegrase abzymes from the sera of HIV-infected patients specifically hydrolyze integrase but nonspecifically cleave short oligopeptides. J. Mol. Recognit. 2012, 25, 193-207. [CrossRef] [PubMed]

135. Townsley-Fuchs, J.; Kam, L.; Fairhurst, R.; Gange, S.J.; Goodglick, L.; Giorgi, J.V.; Sidell, N.; Detels, R.; Braun, J. Human immunodeficiency virus-1 (HIV-1) gp120 superantigen-binding serum antibodies. A host factor in homosexual HIV-1 transmission. J. Clin. Investig. 1996, 98, 1794-1801. [CrossRef] [PubMed]

136. Planque, S.; Mitsuda, Y.; Taguchi, H.; Salas, M.; Morris, M.-K.; Nishiyama, Y.; Kyle, R.; Okhuysen, P.; Escobar, M.; Hunter, R.; et al. Characterization of gp120 Hydrolysis by IgA Antibodies from Humans without HIV Infection. AIDS Res. Hum. Retroviruses 2007, 23, 1541-1554. [CrossRef]

137. Paul, S.; Karle, S.; Planque, S.; Taguchi, H.; Salas, M.; Nishiyama, Y.; Handy, B.; Hunter, R.; Edmundson, A.; Hanson, C. Naturally occurring proteolytic antibodies: Selective immunoglobulin M-catalyzed hydrolysis of HIV gp120. J. Biol. Chem. 2004, 279, 39611-39619. [CrossRef]

138. Gao, Q.-S.; Sun, M.; Rees, A.R.; Paul, S. Site-directed Mutagenesis of Proteolytic Antibody Light Chain. J. Mol. Biol. 1995, 253, 658-664. [CrossRef]

139. Chorny, A.; Puga, I.; Cerutti, A. Innate Signalling Networks in Mucosal IgA Class Switching. Adv Immunol 2010, 107, 31-69. [CrossRef]

140. Olshevsky, U.; Helseth, E.; Furman, C.; Li, J.; Haseltine, W.; Sodroski, J. Identification of individual human immunodeficiency virus type 1 gp120 amino acids important for CD4 receptor binding. J. Virol. 1990, 64, 5701-5707. [CrossRef]

141. Nishiyama, Y.; Karle, S.; Planque, S.; Taguchi, H.; Paul, S. Antibodies to the superantigenic site of HIV-1 gp120: Hydrolytic and binding activities of the light chain subunit. Mol. Immunol. 2007, 44, 2707-2718. [CrossRef] [PubMed]

142. Belogurov, A.; Kozyr, A.; Ponomarenko, N.; Gabibov, A. Catalytic antibodies: Balancing between Dr. Jekyll and Mr. Hyde. Bioessays 2009, 31, 1161-1171. [CrossRef] [PubMed]

143. Odintsova, E.S.; Dmitrenok, P.S.; Buneva, V.N.; Nevinsky, G.A. Specific anti-integrase abzymes from HIV-infected patients: A comparison of the cleavage sites of intact globular HIV integrase and two 20-mer oligopeptides corresponding to its antigenic determinants. J. Mol. Recognit. 2013, 26, 121-135. [CrossRef] [PubMed]

144. Odintsova, E.S.; Dmitrenok, P.S.; Timofeeva, A.M.; Buneva, V.N.; Nevinsky, G.A. Why specific anti-integrase antibodies from HIV-infected patients can efficiently hydrolyze 21-mer oligopeptide corresponding to antigenic determinant of human myelin basic protein. J. Mol. Recognit. 2014, 27, 32-45. [CrossRef] [PubMed] 
145. Paul, S.; Li, L.; Kalaga, R.; Wilkins-Stevens, P.; Stevens, F.J.; Solomon, A. Natural Catalytic Antibodies: Peptide-hydrolyzing Activities of Bence Jones Proteins and VL Fragment. J. Biol. Chem. 1995, 270, 15257-15261. [CrossRef]

146. Paul, S.; Li, L.; Kalaga, R.; O'Dell, J.; Dannenbring, R.E.; Swindells, S.; Hinrichs, S.; Caturegli, P.; Rose, N.R. Characterization of thyroglobulin-directed and polyreactive catalytic antibodies in autoimmune disease. J. Immunol. 1997, 159, $1530-1536$.

147. Ponomarenko, N.A.; Durova, O.M.; Vorobiev, I.I.; Belogurov, A.A.; Kurkova, I.N.; Petrenko, A.G.; Telegin, G.B.; Suchkov, S.V.; Kiselev, S.L.; Lagarkova, M.A.; et al. Autoantibodies to myelin basic protein catalyze site-specific degradation of their antigen. Proc. Natl. Acad. Sci. USA 2006, 103, 281-286. [CrossRef]

148. Nevinsky, G.A. How Enzymes, Proteins, and Antibodies Recognize Extended DNAs; General Regularities. Int. J. Mol. Sci. 2021, 22, 1369. [CrossRef]

149. Nevinsky, G.A.; Buneva, V.N. Natural catalytic antibodies in norm, autoimmune, viral, and bacterial diseases. Sci. World J. 2010, 10, 820417. [CrossRef]

150. Odintsova, E.S.; Dmitrenok, P.S.; Baranova, S.V.; Timofeeva, A.M.; Buneva, V.N.; Nevinsky, G.A. Features of hydrolysis of specific and nonspecific globular proteins and oligopeptides by antibodies against viral integrase from blood of HIV-infected patients. Biochemistry 2015, 80, 180-201. [CrossRef]

151. Baranova, S.V.; Dmitrenok, P.S.; Buneva, V.N.; Sedykh, S.E.; Nevinsky, G.A. HIV-Infected Patients: Cross Site-Specific Hydrolysis of H3 and H4 Histones and Myelin Basic Protein with Antibodies against These Three Proteins. Molecules 2021, 26, 316. [CrossRef] [PubMed]

152. Gololobov, G.V.; Mikhalap, S.V.; Starov, A.V.; Kolesnikov, A.F.; Gabibov, A.G. DNA-protein complexes. Appl. Biochem. Biotechnol. 1994, 47, 305-315. [CrossRef] [PubMed]

153. Legostaeva, G.A.; Polosukhina, D.I.; Bezuglova, A.M.; Doronin, B.M.; Buneva, V.N.; Nevinsky, G.A. Affinity and catalytic heterogeneity of polyclonal myelin basic protein-hydrolyzing IgGs from sera of patients with multiple sclerosis. J. Cell. Mol. Med. 2010, 14, 699-709. [CrossRef]

154. Bezuglova, A.M.; Konenkova, L.P.; Buneva, V.N.; Nevinsky, G.A. IgGs containing light chains of the $\lambda$ - and $k-$ type and of all subclasses (IgG1-IgG4) from the sera of patients with systemic lupus erythematosus hydrolyze myelin basic protein. Int. Immunol. 2012, 24, 759-770. [CrossRef]

155. Bezuglova, A.M.; Konenkova, L.P.; Doronin, B.M.; Buneva, V.N.; Nevinsky, G.A. Affinity and catalytic heterogeneity and metal-dependence of polyclonal myelin basic protein-hydrolyzing IgGs from sera of patients with systemic lupus erythematosus. J. Mol. Recognit. 2011, 24, 960-974. [CrossRef] [PubMed]

156. Gulick, R.M.; Flexner, C. Long-Acting HIV Drugs for Treatment and Prevention. Annu. Rev. Med. 2019, 70, 137-150. [CrossRef]

157. Haynes, B.F.; Burton, D.R. Developing an HIV vaccine. Science 2017, 355, 1129-1130. [CrossRef] [PubMed]

158. Seaman, M.S.; Janes, H.; Hawkins, N.; Grandpre, L.E.; Devoy, C.; Giri, A.; Coffey, R.T.; Harris, L.; Wood, B.; Daniels, M.G.; et al. Tiered Categorization of a Diverse Panel of HIV-1 Env Pseudoviruses for Assessment of Neutralizing Antibodies. J. Virol. 2010, 84, 1439-1452. [CrossRef]

159. Sarzotti-Kelsoe, M.; Bailer, R.T.; Turk, E.; Lin, C.; Bilska, M.; Greene, K.M.; Gao, H.; Todd, C.A.; Ozaki, D.A.; Seaman, M.S.; et al. Optimization and validation of the TZM-bl assay for standardized assessments of neutralizing antibodies against HIV-1. J. Immunol. Methods 2014, 409, 131-146. [CrossRef]

160. Montefiori, D.C.; Roederer, M.; Morris, L.; Seaman, M.S. Neutralization tiers of HIV-1. Curr. Opin. HIV AIDS 2018, 13, 128-136. [CrossRef]

161. Früh, K.; Picker, L. CD8+ T cell programming by cytomegalovirus vectors: Applications in prophylactic and therapeutic vaccination. Curr. Opin. Immunol. 2017, 47, 52-56. [CrossRef] [PubMed]

162. Mascola, J.R.; D'Souza, P.; Gilbert, P.; Hahn, B.H.; Haigwood, N.L.; Morris, L.; Petropoulos, C.J.; Polonis, V.R.; Sarzotti, M.; Montefiori, D.C. Recommendations for the Design and Use of Standard Virus Panels To Assess Neutralizing Antibody Responses Elicited by Candidate Human Immunodeficiency Virus Type 1 Vaccines. J. Virol. 2005, 79, 10103-10107. [CrossRef] [PubMed]

163. Moldt, B.; Rakasz, E.G.; Schultz, N.; Chan-Hui, P.-Y.; Swiderek, K.; Weisgrau, K.L.; Piaskowski, S.M.; Bergman, Z.; Watkins, D.I.; Poignard, P.; et al. Highly potent HIV-specific antibody neutralization in vitro translates into effective protection against mucosal SHIV challenge in vivo. Proc. Natl. Acad. Sci. USA 2012, 109, 18921-18925. [CrossRef]

164. Moog, C.; Dereuddre-Bosquet, N.; Teillaud, J.-L.; Biedma, M.E.; Holl, V.; Van Ham, G.; Heyndrickx, L.; Van Dorsselaer, A.; Katinger, D.; Vcelar, B.; et al. Protective effect of vaginal application of neutralizing and nonneutralizing inhibitory antibodies against vaginal SHIV challenge in macaques. Mucosal Immunol. 2014, 7, 46-56. [CrossRef]

165. Kwong, P.D.; Mascola, J.R.; Nabel, G.J. Broadly neutralizing antibodies and the search for an HIV-1 vaccine: The end of the beginning. Nat. Rev. Immunol. 2013, 13, 693-701. [CrossRef] [PubMed]

166. Haut, L.H.; Ertl, H.C.J. Obstacles to the successful development of an efficacious T cell-inducing HIV-1 vaccine. J. Leukoc. Biol. 2009, 86, 779-793. [CrossRef] [PubMed]

167. Zolla-Pazner, S.; Cohen, S.; Pinter, A.; Krachmarov, C.; Wrin, T.; Wang, S.; Lu, S. Cross-clade neutralizing antibodies against HIV-1 induced in rabbits by focusing the immune response on a neutralizing epitope. Virology 2009, 392, 82-93. [CrossRef] [PubMed]

168. Forthal, D.N.; Landucci, G.; Cole, K.S.; Marthas, M.; Becerra, J.C.; Van Rompay, K. Rhesus Macaque Polyclonal and Monoclonal Antibodies Inhibit Simian Immunodeficiency Virus in the Presence of Human or Autologous Rhesus Effector Cells. J. Virol. 2006, 80, 9217-9225. [CrossRef] 
169. Gómez-Román, V.R.; Patterson, L.J.; Venzon, D.; Liewehr, D.; Aldrich, K.; Florese, R.; Robert-Guroff, M. Vaccine-Elicited Antibodies Mediate Antibody-Dependent Cellular Cytotoxicity Correlated with Significantly Reduced Acute Viremia in Rhesus Macaques Challenged with SIV mac251. J. Immunol. 2005, 174, 2185-2189. [CrossRef] [PubMed]

170. Kwong, P.D.; Mascola, J.R. Human Antibodies that Neutralize HIV-1: Identification, Structures, and B Cell Ontogenies. Immunity 2012, 37, 412-425. [CrossRef]

171. Briney, B.S.; Willis, J.R.; Crowe, J.E. Human Peripheral Blood Antibodies with Long HCDR3s Are Established Primarily at Original Recombination Using a Limited Subset of Germline Genes. PLoS ONE 2012, 7, e36750. [CrossRef] [PubMed]

172. Yu, L.; Guan, Y. Immunologic Basis for Long HCDR3s in Broadly Neutralizing Antibodies Against HIV-1. Front. Immunol. 2014, 5, 250. [CrossRef] [PubMed]

173. Steichen, J.M.; Lin, Y.-C.; Havenar-Daughton, C.; Pecetta, S.; Ozorowski, G.; Willis, J.R.; Toy, L.; Sok, D.; Liguori, A.; Kratochvil, S.; et al. A generalized HIV vaccine design strategy for priming of broadly neutralizing antibody responses. Science 2019, 366, aax4380. [CrossRef] [PubMed]

174. Flemming, A. bnAbs for HIV: Shepherding towards improbable mutations. Nat. Rev. Drug Discov. 2020, 19, 90. [CrossRef] [PubMed]

175. Willis, J.R.; Finn, J.A.; Briney, B.; Sapparapu, G.; Singh, V.; King, H.; LaBranche, C.C.; Montefiori, D.C.; Meiler, J.; Crowe, J.E. Long antibody HCDR3s from HIV-naïve donors presented on a PG9 neutralizing antibody background mediate HIV neutralization. Proc. Natl. Acad. Sci. USA 2016, 113, 4446-4451. [CrossRef]

176. Finney, J.; Kelsoe, G. Poly- and autoreactivity of HIV-1 bNAbs: Implications for vaccine design. Retrovirology 2018, 15, 53. [CrossRef]

177. Deeks, S.G.; Schweighardt, B.; Wrin, T.; Galovich, J.; Hoh, R.; Sinclair, E.; Hunt, P.; McCune, J.M.; Martin, J.N.; Petropoulos, C.J.; et al. Neutralizing Antibody Responses against Autologous and Heterologous Viruses in Acute versus Chronic Human Immunodeficiency Virus (HIV) Infection: Evidence for a Constraint on the Ability of HIV To Completely Evade Neutralizing Antibody Responses. J. Virol. 2006, 80, 6155-6164. [CrossRef]

178. Draenert, R.; Allen, T.M.; Liu, Y.; Wrin, T.; Chappey, C.; Verrill, C.L.; Sirera, G.; Eldridge, R.L.; Lahaie, M.P.; Ruiz, L.; et al Constraints on HIV-1 evolution and immunodominance revealed in monozygotic adult twins infected with the same virus. J. Exp. Med. 2006, 203, 529-539. [CrossRef]

179. Verkoczy, L.; Diaz, M. Autoreactivity in HIV-1 broadly neutralizing antibodies. Curr. Opin. HIV AIDS 2014, 9, 224-234. [CrossRef]

180. Verkoczy, L.; Diaz, M.; Holl, T.M.; Ouyang, Y.-B.; Bouton-Verville, H.; Alam, S.M.; Liao, H.-X.; Kelsoe, G.; Haynes, B.F. Autoreactivity in an HIV-1 broadly reactive neutralizing antibody variable region heavy chain induces immunologic tolerance. Proc. Natl. Acad. Sci. USA 2010, 107, 181-186. [CrossRef]

181. Pugh-Bernard, A.E.; Silverman, G.J.; Cappione, A.J.; Villano, M.E.; Ryan, D.H.; Insel, R.A.; Sanz, I. Regulation of inherently autoreactive VH4-34 B cells in the maintenance of human B cell tolerance. J. Clin. Investig. 2001, 108, 1061-1070. [CrossRef] [PubMed]

182. Mehandru, S.; Poles, M.A.; Tenner-Racz, K.; Horowitz, A.; Hurley, A.; Hogan, C.; Boden, D.; Racz, P.; Markowitz, M. Primary HIV-1 Infection Is Associated with Preferential Depletion of CD4 ${ }^{+}$T Lymphocytes from Effector Sites in the Gastrointestinal Tract. J. Exp. Med. 2004, 200, 761-770. [CrossRef] [PubMed]

183. Katlama, C.; Deeks, S.G.; Autran, B.; Martinez-Picado, J.; van Lunzen, J.; Rouzioux, C.; Miller, M.; Vella, S.; Schmitz, J.E.; Ahlers, J.; et al. Barriers to a cure for HIV: New ways to target and eradicate HIV-1 reservoirs. Lancet 2013, 381, 2109-2117. [CrossRef]

184. Pavot, V.; Rochereau, N.; Lawrence, P.; Girard, M.P.; Genin, C.; Verrier, B.; Paul, S. Recent progress in HIV vaccines inducing mucosal immune responses. AIDS 2014, 28, 1701-1718. [CrossRef] [PubMed]

185. Alexander, R.; Mestecky, J. Neutralizing Antibodies in Mucosal Secretions: IgG or IgA? Curr. HIV Res. 2007, 5, 588-593. [CrossRef] [PubMed]

186. Watkins, J.D.; Sholukh, A.M.; Mukhtar, M.M.; Siddappa, N.B.; Lakhashe, S.K.; Kim, M.; Reinherz, E.L.; Gupta, S.; Forthal, D.N.; Sattentau, Q.J.; et al. Anti-HIV IgA isotypes. AIDS 2013, 27, F13-F20. [CrossRef] [PubMed]

187. Shacklett, B.L. Mucosal immunity to HIV: A review of recent literature. Curr. Opin. HIV AIDS 2008, 3, 541-547. [CrossRef]

188. Choi, R.Y.; Levinson, P.; Guthrie, B.L.; Lohman-Payne, B.; Bosire, R.; Liu, A.Y.; Hirbod, T.; Kiarie, J.; Overbaugh, J.; John-Stewart, G.; et al. Cervicovaginal HIV-1-neutralizing immunoglobulin A detected among HIV-1-exposed seronegative female partners in HIV-1-discordant couples. AIDS 2012, 26, 2155-2163. [CrossRef]

189. Lin, S.W.; Cun, A.S.; Harris-McCoy, K.; Ertl, H.C. Intramuscular rather than oral administration of replication-defective adenoviral vaccine vector induces specific CD8+ T cell responses in the gut. Vaccine 2007, 25, 2187-2193. [CrossRef]

190. Tatsis, N.; Lin, S.-W.; Harris-McCoy, K.; Garber, D.A.; Feinberg, M.B.; Ertl, H.C.J. Multiple immunizations with adenovirus and MVA vectors improve CD8+ T cell functionality and mucosal homing. Virology 2007, 367, 156-167. [CrossRef]

191. Pavot, V.; Rochereau, N.; Genin, C.; Verrier, B.; Paul, S. New insights in mucosal vaccine development. Vaccine 2012, 30, 142-154. [CrossRef] [PubMed]

192. Johansson, E.-L.; Bergquist, C.; Edebo, A.; Johansson, C.; Svennerholm, A.-M. Comparison of different routes of vaccination for eliciting antibody responses in the human stomach. Vaccine 2004, 22, 984-990. [CrossRef] [PubMed]

193. Johansson, E.-L.; Wassén, L.; Holmgren, J.; Jertborn, M.; Rudin, A. Nasal and Vaginal Vaccinations Have Differential Effects on Antibody Responses in Vaginal and Cervical Secretions in Humans. Infect. Immun. 2001, 69, 7481-7486. [CrossRef] [PubMed] 
194. Jones, A.T.; Shen, X.; Walter, K.L.; LaBranche, C.C.; Wyatt, L.S.; Tomaras, G.D.; Montefiori, D.C.; Moss, B.; Barouch, D.H.; Clements, J.D.; et al. HIV-1 vaccination by needle-free oral injection induces strong mucosal immunity and protects against SHIV challenge. Nat. Commun. 2019, 10, 798. [CrossRef]

195. Doan, L.X.; Li, M.; Chen, C.; Yao, Q. Virus-like particles as HIV-1 vaccines. Rev. Med. Virol. 2005, 15, 75-88. [CrossRef]

196. Young, K.R.; McBurney, S.P.; Karkhanis, L.U.; Ross, T.M. Virus-like particles: Designing an effective AIDS vaccine. Methods 2006, 40, 98-117. [CrossRef]

197. Stanley, M.; Pinto, L.A.; Trimble, C. Human Papillomavirus Vaccines-Immune Responses. Vaccine 2012, 30, F83-F87. [CrossRef]

198. Landry, N.; Ward, B.J.; Trépanier, S.; Montomoli, E.; Dargis, M.; Lapini, G.; Vézina, L.-P. Preclinical and Clinical Development of Plant-Made Virus-Like Particle Vaccine against Avian H5N1 Influenza. PLoS ONE 2010, 5, e15559. [CrossRef]

199. Mestecky, J.; Russell, M.W.; Elson, C.O. Perspectives on Mucosal Vaccines: Is Mucosal Tolerance a Barrier? J. Immunol. 2007, 179, 5633-5638. [CrossRef]

200. Kang, S.; Hong, S.; Lee, Y.-K.; Cho, S. Oral Vaccine Delivery for Intestinal Immunity—Biological Basis, Barriers, Delivery System, and M Cell Targeting. Polymers 2018, 10, 948. [CrossRef]

201. Ogra, P.L.; Faden, H.; Welliver, R.C. Vaccination Strategies for Mucosal Immune Responses. Clin. Microbiol. Rev. 2001, 14, 430-445. [CrossRef] [PubMed]

202. Lavelle, E.C.; Ward, R.W. Mucosal vaccines-Fortifying the frontiers. Nat. Rev. Immunol. 2021. [CrossRef] [PubMed]

203. Sanders, R.W.; Venturi, M.; Schiffner, L.; Kalyanaraman, R.; Katinger, H.; Lloyd, K.O.; Kwong, P.D.; Moore, J.P. The MannoseDependent Epitope for Neutralizing Antibody 2G12 on Human Immunodeficiency Virus Type 1 Glycoprotein gp120. J. Virol. 2002, 76, 7293-7305. [CrossRef] [PubMed]

204. Karle, S.; Planque, S.; Nishiyama, Y.; Taguchi, H.; Zhou, Y.-X.; Salas, M.; Lake, D.; Thiagarajan, P.; Arnett, F.; Hanson, C.V.; et al Cross-clade HIV-1 neutralization by an antibody fragment from a lupus phage display library. AIDS 2004, 18, 329-331. [CrossRef]

205. Planque, S.; Salas, M.; Mitsuda, Y.; Sienczyk, M.; Escobar, M.A.; Mooney, J.P.; Morris, M.-K.; Nishiyama, Y.; Ghosh, D.; Kumar, A.; et al. Neutralization of genetically diverse HIV-1 strains by IgA antibodies to the gp120-CD4-binding site from long-term survivors of HIV infection. AIDS 2010, 24, 875-884. [CrossRef]

206. Mu, Z.; Haynes, B.F.; Cain, D.W. HIV mRNA Vaccines-Progress and Future Paths. Vaccines 2021, 9, 134. [CrossRef]

207. Pardi, N.; Hogan, M.J.; Naradikian, M.S.; Parkhouse, K.; Cain, D.W.; Jones, L.; Moody, M.A.; Verkerke, H.P.; Myles, A.; Willis, E.; et al. Nucleoside-modified mRNA vaccines induce potent $\mathrm{T}$ follicular helper and germinal center B cell responses. J. Exp. Med. 2018, 215, 1571-1588. [CrossRef]

208. Cirelli, K.M.; Carnathan, D.G.; Nogal, B.; Martin, J.T.; Rodriguez, O.L.; Upadhyay, A.A.; Enemuo, C.A.; Gebru, E.H.; Choe, Y.; Viviano, F.; et al. Slow Delivery Immunization Enhances HIV Neutralizing Antibody and Germinal Center Responses via Modulation of Immunodominance. Cell 2020, 180, 206. [CrossRef]

209. Moyer, T.J.; Zmolek, A.C.; Irvine, D.J. Beyond antigens and adjuvants: Formulating future vaccines. J. Clin. Investig. 2016, 126, 799-808. [CrossRef]

210. Gause, K.T.; Wheatley, A.K.; Cui, J.; Yan, Y.; Kent, S.J.; Caruso, F. Immunological Principles Guiding the Rational Design of Particles for Vaccine Delivery. ACS Nano 2017, 11, 54-68. [CrossRef]

211. López-Sagaseta, J.; Malito, E.; Rappuoli, R.; Bottomley, M.J. Self-assembling protein nanoparticles in the design of vaccines Comput. Struct. Biotechnol. J. 2016, 14, 58-68. [CrossRef] [PubMed]

212. Sliepen, K.; Ozorowski, G.; Burger, J.A.; van Montfort, T.; Stunnenberg, M.; LaBranche, C.; Montefiori, D.C.; Moore, J.P.; Ward, A.B.; Sanders, R.W. Presenting native-like HIV-1 envelope trimers on ferritin nanoparticles improves their immunogenicity. Retrovirology 2015, 12, 82. [CrossRef] [PubMed]

213. He, L.; de Val, N.; Morris, C.D.; Vora, N.; Thinnes, T.C.; Kong, L.; Azadnia, P.; Sok, D.; Zhou, B.; Burton, D.R.; et al. Presenting native-like trimeric HIV-1 antigens with self-assembling nanoparticles. Nat. Commun. 2016, 7, 12041. [CrossRef] [PubMed]

214. Pardi, N.; Hogan, M.J.; Weissman, D. Recent advances in mRNA vaccine technology. Curr. Opin. Immunol. 2020, 65, 14-20. [CrossRef]

215. Zhang, P.; Gorman, J.; Geng, H.; Liu, Q.; Lin, Y.; Tsybovsky, Y.; Go, E.P.; Dey, B.; Andine, T.; Kwon, A.; et al. Interdomain Stabilization Impairs CD4 Binding and Improves Immunogenicity of the HIV-1 Envelope Trimer. Cell Host Microbe 2018, 23, 832-844.e6. [CrossRef]

216. Henderson, R.; Lu, M.; Zhou, Y.; Mu, Z.; Parks, R.; Han, Q.; Hsu, A.L.; Carter, E.; Blanchard, S.C.; Edwards, R.J.; et al. Disruption of the HIV-1 Envelope allosteric network blocks CD4-induced rearrangements. Nat. Commun. 2020, 11, 520. [CrossRef]

217. Do Kwon, Y.; Pancera, M.; Acharya, P.; Georgiev, I.S.; Crooks, E.T.; Gorman, J.; Joyce, M.G.; Guttman, M.; Ma, X.; Narpala, S.; et al. Crystal structure, conformational fixation and entry-related interactions of mature ligand-free HIV-1 Env. Nat. Struct. Mol. Biol. 2015, 22, 522-531. [CrossRef]

218. Saunders, K.O.; Wiehe, K.; Tian, M.; Acharya, P.; Bradley, T.; Alam, S.M.; Go, E.P.; Scearce, R.; Sutherland, L.; Henderson, R.; et al. Targeted selection of HIV-specific antibody mutations by engineering B cell maturation. Science 2019, 366, eaay7199. [CrossRef] [PubMed]

219. Khaitan, A.; Unutmaz, D. Revisiting Immune Exhaustion During HIV Infection. Curr. HIV/AIDS Rep. 2011, 8, 4-11. [CrossRef]

220. Zajac, A.J.; Blattman, J.N.; Murali-Krishna, K.; Sourdive, D.J.D.; Suresh, M.; Altman, J.D.; Ahmed, R. Viral Immune Evasion Due to Persistence of Activated T Cells Without Effector Function. J. Exp. Med. 1998, 188, 2205-2213. [CrossRef] 
221. Urbani, S.; Amadei, B.; Tola, D.; Massari, M.; Schivazappa, S.; Missale, G.; Ferrari, C. PD-1 Expression in Acute Hepatitis C Virus (HCV) Infection Is Associated with HCV-Specific CD8 Exhaustion. J. Virol. 2006, 80, 11398-11403. [CrossRef] [PubMed]

222. Radziewicz, H.; Ibegbu, C.C.; Fernandez, M.L.; Workowski, K.A.; Obideen, K.; Wehbi, M.; Hanson, H.L.; Steinberg, J.P.; Masopust, D.; Wherry, E.J.; et al. Liver-Infiltrating Lymphocytes in Chronic Human Hepatitis C Virus Infection Display an Exhausted Phenotype with High Levels of PD-1 and Low Levels of CD127 Expression. J. Virol. 2007, 81, 2545-2553. [CrossRef] [PubMed]

223. Boni, C.; Fisicaro, P.; Valdatta, C.; Amadei, B.; Di Vincenzo, P.; Giuberti, T.; Laccabue, D.; Zerbini, A.; Cavalli, A.; Missale, G.; et al. Characterization of Hepatitis B Virus (HBV)-Specific T-Cell Dysfunction in Chronic HBV Infection. J. Virol. 2007, 81, 4215-4225. [CrossRef] [PubMed]

224. Wherry, E.J.; Kurachi, M. Molecular and cellular insights into T cell exhaustion. Nat. Rev. Immunol. 2015, 15, 486-499. [CrossRef]

225. Hashimoto, M.; Kamphorst, A.O.; Im, S.J.; Kissick, H.T.; Pillai, R.N.; Ramalingam, S.S.; Araki, K.; Ahmed, R. CD8 T Cell Exhaustion in Chronic Infection and Cancer: Opportunities for Interventions. Annu. Rev. Med. 2018, 69, 301-318. [CrossRef]

226. Kahan, S.M.; Wherry, E.J.; Zajac, A.J. T cell exhaustion during persistent viral infections. Virology 2015, 479-480, 180-193. [CrossRef]

227. Trautmann, L.; Janbazian, L.; Chomont, N.; Said, E.A.; Gimmig, S.; Bessette, B.; Boulassel, M.-R.; Delwart, E.; Sepulveda, H.; Balderas, R.S.; et al. Upregulation of PD-1 expression on HIV-specific CD8+ T cells leads to reversible immune dysfunction. Nat. Med. 2006, 12, 1198-1202. [CrossRef]

228. Petrovas, C.; Casazza, J.P.; Brenchley, J.M.; Price, D.A.; Gostick, E.; Adams, W.C.; Precopio, M.L.; Schacker, T.; Roederer, M.; Douek, D.C.; et al. PD-1 is a regulator of virus-specific CD8+ T cell survival in HIV infection. J. Exp. Med. 2006, 203, 2281-2292. [CrossRef]

229. Wherry, E.J.; Ha, S.-J.; Kaech, S.M.; Haining, W.N.; Sarkar, S.; Kalia, V.; Subramaniam, S.; Blattman, J.N.; Barber, D.L.; Ahmed, R. Molecular Signature of CD8+ T Cell Exhaustion during Chronic Viral Infection. Immunity 2007, 27, 670-684. [CrossRef]

230. D’Souza, M.; Fontenot, A.P.; Mack, D.G.; Lozupone, C.; Dillon, S.; Meditz, A.; Wilson, C.C.; Connick, E.; Palmer, B.E. Programmed Death 1 Expression on HIV-Specific CD4 + T Cells Is Driven by Viral Replication and Associated with T Cell Dysfunction. J. Immunol. 2007, 179, 1979-1987. [CrossRef]

231. Kaufmann, D.E.; Walker, B.D. PD-1 and CTLA-4 Inhibitory Cosignaling Pathways in HIV Infection and the Potential for Therapeutic Intervention. J. Immunol. 2009, 182, 5891-5897. [CrossRef] [PubMed]

232. Chomont, N.; El-Far, M.; Ancuta, P.; Trautmann, L.; Procopio, F.A.; Yassine-Diab, B.; Boucher, G.; Boulassel, M.-R.; Ghattas, G.; Brenchley, J.M.; et al. HIV reservoir size and persistence are driven by T cell survival and homeostatic proliferation. Nat. Med. 2009, 15, 893-900. [CrossRef] [PubMed]

233. Fromentin, R.; Bakeman, W.; Lawani, M.B.; Khoury, G.; Hartogensis, W.; DaFonseca, S.; Killian, M.; Epling, L.; Hoh, R.; Sinclair, E.; et al. CD4 ${ }^{+}$T Cells Expressing PD-1, TIGIT and LAG-3 Contribute to HIV Persistence during ART. PLoS Pathog. 2016, 12, e1005761. [CrossRef] [PubMed]

234. Archin, N.M.; Sung, J.M.; Garrido, C.; Soriano-Sarabia, N.; Margolis, D.M. Eradicating HIV-1 infection: Seeking to clear a persistent pathogen. Nat. Rev. Microbiol. 2014, 12, 750-764. [CrossRef] [PubMed]

235. Shan, L.; Deng, K.; Shroff, N.S.; Durand, C.M.; Rabi, S.A.; Yang, H.-C.; Zhang, H.; Margolick, J.B.; Blankson, J.N.; Siliciano, R.F. Stimulation of HIV-1-Specific Cytolytic T Lymphocytes Facilitates Elimination of Latent Viral Reservoir after Virus Reactivation. Immunity 2012, 36, 491-501. [CrossRef]

236. Velu, V.; Titanji, K.; Zhu, B.; Husain, S.; Pladevega, A.; Lai, L.; Vanderford, T.H.; Chennareddi, L.; Silvestri, G.; Freeman, G.J.; et al. Enhancing SIV-specific immunity in vivo by PD-1 blockade. Nature 2009, 458, 206-210. [CrossRef]

237. Cecchinato, V.; Tryniszewska, E.; Ma, Z.M.; Vaccari, M.; Boasso, A.; Tsai, W.-P.; Petrovas, C.; Fuchs, D.; Heraud, J.-M.; Venzon, D.; et al. Immune Activation Driven by CTLA-4 Blockade Augments Viral Replication at Mucosal Sites in Simian Immunodeficiency Virus Infection. J. Immunol. 2008, 180, 5439-5447. [CrossRef]

238. Boyer, Z.; Palmer, S. Targeting Immune Checkpoint Molecules to Eliminate Latent HIV. Front. Immunol. 2018, 9. [CrossRef]

239. Gay, C.L.; Bosch, R.J.; Ritz, J.; Hataye, J.M.; Aga, E.; Tressler, R.L.; Mason, S.W.; Hwang, C.K.; Grasela, D.M.; Ray, N.; et al. Clinical Trial of the Anti-PD-L1 Antibody BMS-936559 in HIV-1 Infected Participants on Suppressive Antiretroviral Therapy. J. Infect. Dis. 2017, 215, 1725-1733. [CrossRef]

240. Wherry, E.J. T cell exhaustion. Nat. Immunol. 2011, 12, 492-499. [CrossRef]

241. Dyavar Shetty, R.; Velu, V.; Titanji, K.; Bosinger, S.E.; Freeman, G.J.; Silvestri, G.; Amara, R.R. PD-1 blockade during chronic SIV infection reduces hyperimmune activation and microbial translocation in rhesus macaques. J. Clin. Investig. 2012, 122, 1712-1716. [CrossRef] [PubMed]

242. Palmer, B.E.; Neff, C.P.; LeCureux, J.; Ehler, A.; DSouza, M.; Remling-Mulder, L.; Korman, A.J.; Fontenot, A.P.; Akkina, R. In Vivo Blockade of the PD-1 Receptor Suppresses HIV-1 Viral Loads and Improves CD4 + T Cell Levels in Humanized Mice. J. Immunol. 2013, 190, 211-219. [CrossRef] [PubMed]

243. Kenmoe, S.; Bigna, J.J.; Fatawou Modiyingi, A.; Ndangang, M.S.; Ngoupo, P.A.; Simo, F.B.N.; Tchatchouang, S.; Temfack, E.; Njouom, R. Case fatality rate and viral aetiologies of acute respiratory tract infections in HIV positive and negative people in Africa: The VARIAFRICA-HIV systematic review and meta-analysis. J. Clin. Virol. 2019, 117, 96-102. [CrossRef] [PubMed]

244. Neuzil, K.M.; Reed, G.W.; Mitchel, E.F., Jr.; Griffin, M.R. Influenza-Associated Morbidity and Mortality in Young and Middle-Aged Women. JAMA 1999, 281, 901-907. [CrossRef] 
245. Sheth, A.N.; Patel, P.; Peters, P.J. Influenza and HIV: Lessons from the 2009 H1N1 Influenza Pandemic. Curr. HIV/AIDS Rep. 2011, 8, 181-191. [CrossRef]

246. Al-Omari, A.; Rabaan, A.A.; Salih, S.; Al-Tawfiq, J.A.; Memish, Z.A. MERS coronavirus outbreak: Implications for emerging viral infections. Diagn. Microbiol. Infect. Dis. 2019, 93, 265-285. [CrossRef]

247. Moni, M.A.; Liò, P. Network-based analysis of comorbidities risk during an infection: SARS and HIV case studies. BMC Bioinform. 2014, 15, 333. [CrossRef]

248. Edelman, E.J.; Aoun-Barakat, L.; Villanueva, M.; Friedland, G. Confronting Another Pandemic: Lessons from HIV can Inform Our COVID-19 Response. AIDS Behav. 2020, 24, 1977-1979. [CrossRef]

249. Jiang, H.; Zhou, Y.; Tang, W. Maintaining HIV care during the COVID-19 pandemic. Lancet HIV 2020, 7, e308-e309. [CrossRef]

250. Blanco, J.L.; Ambrosioni, J.; Garcia, F.; Martínez, E.; Soriano, A.; Mallolas, J.; Miro, J.M. COVID-19 in patients with HIV: Clinical case series. Lancet HIV 2020, 7, e314-e316. [CrossRef]

251. Adepoju, P. Tuberculosis and HIV responses threatened by COVID-19. Lancet HIV 2020, 7, e319-e320. [CrossRef]

252. Algarin, A.B.; Varas-Rodríguez, E.; Valdivia, C.; Fennie, K.P.; Larkey, L.; Hu, N.; Ibañez, G.E. Symptoms, Stress, and HIV-Related Care Among Older People Living with HIV During the COVID-19 Pandemic, Miami, Florida. AIDS Behav. 2020, 24, $2236-2238$. [CrossRef]

253. Harkness, A.; Behar-Zusman, V.; Safren, S.A. Understanding the Impact of COVID-19 on Latino Sexual Minority Men in a US HIV Hot Spot. AIDS Behav. 2020, 24, 2017-2023. [CrossRef] [PubMed]

254. Amimo, F.; Lambert, B.; Magit, A. What does the COVID-19 pandemic mean for HIV, tuberculosis, and malaria control? Trop. Med. Health 2020, 48, 32. [CrossRef] [PubMed]

255. Sun, S.; Hou, J.; Chen, Y.; Lu, Y.; Brown, L.; Operario, D. Challenges to HIV Care and Psychological Health During the COVID-19 Pandemic Among People Living with HIV in China. AIDS Behav. 2020, 24, 2764-2765. [CrossRef]

256. Pinto, R.M.; Park, S. COVID-19 Pandemic Disrupts HIV Continuum of Care and Prevention: Implications for Research and Practice Concerning Community-Based Organizations and Frontline Providers. AIDS Behav. 2020, 24, 2486-2489. [CrossRef]

257. Adadi, P.; Kanwugu, O.N. Living with HIV in the time of COVID-19: A glimpse of hope. J. Med. Virol. 2021, 93, 59-60. [CrossRef]

258. Richardson, S.; Hirsch, J.S.; Narasimhan, M.; Crawford, J.M.; McGinn, T.; Davidson, K.W.; Barnaby, D.P.; Becker, L.B.; Chelico, J.D.; Cohen, S.L.; et al. Presenting Characteristics, Comorbidities, and Outcomes Among 5700 Patients Hospitalized With COVID-19 in the New York City Area. JAMA 2020, 323, 2052-2059. [CrossRef]

259. Shalev, N.; Scherer, M.; LaSota, E.D.; Antoniou, P.; Yin, M.T.; Zucker, J.; Sobieszczyk, M.E. Clinical Characteristics and Outcomes in People Living With Human Immunodeficiency Virus Hospitalized for Coronavirus Disease 2019. Clin. Infect. Dis. 2020, 71, 2294-2297. [CrossRef]

260. Okoh, A.K.; Bishburg, E.; Grinberg, S.; Nagarakanti, S. COVID-19 Pneumonia in Patients with HIV: A Case Series. JAIDS J. Acquir. Immune Defic. Syndr. 2020, 85, e4-e5. [CrossRef]

261. Borobia, A.; Carcas, A.; Arnalich, F.; Álvarez-Sala, R.; Monserrat-Villatoro, J.; Quintana, M.; Figueira, J.; Torres Santos-Olmo, R.; García-Rodríguez, J.; Martín-Vega, A.; et al. A Cohort of Patients with COVID-19 in a Major Teaching Hospital in Europe. J. Clin. Med. 2020, 9, 1733. [CrossRef] [PubMed]

262. Moher, D.; Liberati, A.; Tetzlaff, J.; Altman, D.G. PRISMA Group. Preferred Reporting Items for Systematic Reviews and Meta-Analyses: The PRISMA Statement. PLoS Med. 2009, 6, e1000097. [CrossRef] [PubMed]

263. Cevik, M.; Kuppalli, K.; Kindrachuk, J.; Peiris, M. Virology, transmission, and pathogenesis of SARS-CoV-2. BMJ 2020, 371, m3862. [CrossRef]

264. Sette, A.; Crotty, S. Adaptive immunity to SARS-CoV-2 and COVID-19. Cell 2021, 184, 861-880. [CrossRef]

265. Choi, B.; Choudhary, M.C.; Regan, J.; Sparks, J.A.; Padera, R.F.; Qiu, X.; Solomon, I.H.; Kuo, H.-H.; Boucau, J.; Bowman, K.; et al. Persistence and Evolution of SARS-CoV-2 in an Immunocompromised Host. N. Engl. J. Med. 2020, 383, 2291-2293. [CrossRef]

266. Kemp, S.A.; Collier, D.A.; Datir, R.P.; Ferreira, I.A.T.M.; Gayed, S.; Jahun, A.; Hosmillo, M.; Rees-Spear, C.; Mlcochova, P.; Lumb, I.U.; et al. SARS-CoV-2 evolution during treatment of chronic infection. Nature 2021, 592, 277-282. [CrossRef]

267. Tegally, H.; Wilkinson, E.; Giovanetti, M.; Iranzadeh, A.; Fonseca, V.; Giandhari, J.; Doolabh, D.; Pillay, S.; San, E.J.; Msomi, N.; et al. Detection of a SARS-CoV-2 variant of concern in South Africa. Nature 2021, 592, 438-443. [CrossRef]

268. Faria, N.R.; Mellan, T.A.; Whittaker, C.; Claro, I.M.; Candido, D.D.S.; Mishra, S.; Crispim, M.A.E.; Sales, F.C.S.; Hawryluk, I.; McCrone, J.T.; et al. Genomics and epidemiology of the P.1 SARS-CoV-2 lineage in Manaus, Brazil. Science 2021, 372, 815-821. [CrossRef]

269. Cele, S.; Karim, F.; Lustig, G.; San, J.E.; Hermanus, T.; Tegally, H.; Snyman, J.; Moyo-Gwete, T.; Wilkinson, E.; Bernstein, M.; et al. SARS-CoV-2 prolonged infection during advanced HIV disease evolves extensive immune escape. Cell Host Microbe 2022, 30, 154-162.e5. [CrossRef]

270. Tarhini, H.; Recoing, A.; Bridier-nahmias, A.; Rahi, M.; Lambert, C.; Martres, P.; Lucet, J.-C.; Rioux, C.; Bouzid, D.; Lebourgeois, S.; et al. Long-Term Severe Acute Respiratory Syndrome Coronavirus 2 (SARS-CoV-2) Infectiousness Among Three Immunocompromised Patients: From Prolonged Viral Shedding to SARS-CoV-2 Superinfection. J. Infect. Dis. 2021, 223, $1522-1527$. [CrossRef]

271. Sepulcri, C.; Dentone, C.; Mikulska, M.; Bruzzone, B.; Lai, A.; Fenoglio, D.; Bozzano, F.; Bergna, A.; Parodi, A.; Altosole, T.; et al. The Longest Persistence of Viable SARS-CoV-2 With Recurrence of Viremia and Relapsing Symptomatic COVID-19 in an Immunocompromised Patient-A Case Study. Open Forum Infect. Dis. 2021, 8, ofab217. [CrossRef] [PubMed] 
272. Riou, C.; du Bruyn, E.; Stek, C.; Daroowala, R.; Goliath, R.T.; Abrahams, F.; Said-Hartley, Q.; Allwood, B.W.; Hsiao, N.-Y.; Wilkinson, K.A.; et al. Relationship of SARS-CoV-2-specific CD4 response to COVID-19 severity and impact of HIV-1 and tuberculosis coinfection. J. Clin. Investig. 2021, 131, e149125. [CrossRef] [PubMed]

273. Karim, F.; Gazy, I.; Cele, S.; Zungu, Y.; Krause, R.; Bernstein, M.; Khan, K.; Ganga, Y.; Rodel, H.; Mthabela, N.; et al. HIV status alters disease severity and immune cell responses in Beta variant SARS-CoV-2 infection wave. Elife 2021, 10. [CrossRef]

274. Spinelli, M.A.; Lynch, K.L.; Yun, C.; Glidden, D.V.; Peluso, M.J.; Henrich, T.J.; Gandhi, M.; Brown, L.B. SARS-CoV-2 seroprevalence, and IgG concentration and pseudovirus neutralising antibody titres after infection, compared by HIV status: A matched casecontrol observational study. Lancet HIV 2021, 8, e334-e341. [CrossRef]

275. Israelow, B.; Mao, T.; Klein, J.; Song, E.; Menasche, B.; Omer, S.B.; Iwasaki, A. Adaptive immune determinants of viral clearance and protection in mouse models of SARS-CoV-2. Sci. Immunol. 2021, 6, eabl4509. [CrossRef]

276. Carmona, S.; Bor, J.; Nattey, C.; Maughan-Brown, B.; Maskew, M.; Fox, M.P.; Glencross, D.K.; Ford, N.; MacLeod, W.B. Persistent High Burden of Advanced HIV Disease Among Patients Seeking Care in South Africa's National HIV Program: Data From a Nationwide Laboratory Cohort. Clin. Infect. Dis. 2018, 66, S111-S117. [CrossRef]

277. Huerga, H.; Van Cutsem, G.; Ben Farhat, J.; Puren, A.; Bouhenia, M.; Wiesner, L.; Dlamini, L.; Maman, D.; Ellman, T.; Etard, J.-F. Progress towards the UNAIDS 90-90-90 goals by age and gender in a rural area of KwaZulu-Natal, South Africa: A household-based community cross-sectional survey. BMC Public Health 2018, 18, 303. [CrossRef]

278. Madhi, S.; Koen, A.; Fairlie, L.; Cutland, C.; Baillie, V.; Padayachee, S.; Dheda, K.; Barnabas, S.; Bhorat, Q.E.; Briner, C.; et al ChAdOx1 nCoV-19 (AZD1222) Vaccine in People Living with and without HIV; Research Square: Durham, NC, USA, 2021. [CrossRef]

279. Jordan, R.E.; Adab, P.; Cheng, K.K. COVID-19: Risk factors for severe disease and death. BMJ 2020, 368, m1198. [CrossRef]

280. Cooper, T.; Woodward, B.; Alom, S.; Harky, A. Coronavirus disease 2019 (COVID-19) outcomes in HIV/AIDS patients: A systematic review. HIV Med. 2020, 21, 567-577. [CrossRef]

281. Huang, C.; Wang, Y.; Li, X.; Ren, L.; Zhao, J.; Hu, Y.; Zhang, L.; Fan, G.; Xu, J.; Gu, X.; et al. Clinical features of patients infected with 2019 novel coronavirus in Wuhan, China. Lancet 2020, 395, 497-506. [CrossRef]

282. Xu, Z.; Shi, L.; Wang, Y.; Zhang, J.; Huang, L.; Zhang, C.; Liu, S.; Zhao, P.; Liu, H.; Zhu, L.; et al. Pathological findings of COVID-19 associated with acute respiratory distress syndrome. Lancet Respir. Med. 2020, 8, 420-422. [CrossRef]

283. Qin, C.; Zhou, L.; Hu, Z.; Zhang, S.; Yang, S.; Tao, Y.; Xie, C.; Ma, K.; Shang, K.; Wang, W.; et al. Dysregulation of Immune Response in Patients With Coronavirus 2019 (COVID-19) in Wuhan, China. Clin. Infect. Dis. 2020, 71, 762-768. [CrossRef]

284. Tan, M.; Liu, Y.; Zhou, R.; Deng, X.; Li, F.; Liang, K.; Shi, Y. Immunopathological characteristics of coronavirus disease 2019 cases in Guangzhou, China. Immunology 2020, 160, 261-268. [CrossRef] [PubMed]

285. XU, B.; FAN, C.; WANG, A.; ZOU, Y.; YU, Y.; HE, C.; XIA, W.; ZHANG, J.; MIAO, Q. Suppressed T cell-mediated immunity in patients with COVID-19: A clinical retrospective study in Wuhan, China. J. Infect. 2020, 81, e51-e60. [CrossRef] [PubMed]

286. Wan, S.; Yi, Q.; Fan, S.; Lv, J.; Zhang, X.; Guo, L.; Lang, C.; Xiao, Q.; Xiao, K.; Yi, Z.; et al. Relationships among lymphocyte subsets, cytokines, and the pulmonary inflammation index in coronavirus (COVID-19) infected patients. Br. J. Haematol. 2020, 189, 428-437. [CrossRef]

287. Zhou, Y.; Zhang, Z.; Tian, J.; Xiong, S. Risk factors associated with disease progression in a cohort of patients infected with the 2019 novel coronavirus. Ann. Palliat. Med. 2020, 9, 428-436. [CrossRef]

288. Chen, Y.; Klein, S.L.; Garibaldi, B.T.; Li, H.; Wu, C.; Osevala, N.M.; Li, T.; Margolick, J.B.; Pawelec, G.; Leng, S.X. Aging in COVID-19: Vulnerability, immunity and intervention. Ageing Res. Rev. 2021, 65, 101205. [CrossRef]

289. Channappanavar, R.; Perlman, S. Pathogenic human coronavirus infections: Causes and consequences of cytokine storm and immunopathology. Semin. Immunopathol. 2017, 39, 529-539. [CrossRef]

290. Lau, S.K.P.; Lau, C.C.Y.; Chan, K.-H.; Li, C.P.Y.; Chen, H.; Jin, D.-Y.; Chan, J.F.W.; Woo, P.C.Y.; Yuen, K.-Y. Delayed induction of proinflammatory cytokines and suppression of innate antiviral response by the novel Middle East respiratory syndrome coronavirus: Implications for pathogenesis and treatment. J. Gen. Virol. 2013, 94, 2679-2690. [CrossRef]

291. Moore, J.B.; June, C.H. Cytokine release syndrome in severe COVID-19. Science 2020, 368, 473-474. [CrossRef]

292. Guo, W.; Ming, F.; Dong, Y.; Zhang, Q.; Zhang, X.; Mo, P.; Feng, Y.; Liang, K. A Survey for COVID-19 Among HIV/AIDS Patients in Two Districts of Wuhan, China. SSRN Electron. J. 2020. [CrossRef]

293. Minotti, C.; Tirelli, F.; Barbieri, E.; Giaquinto, C.; Donà, D. How is immunosuppressive status affecting children and adults in SARS-CoV-2 infection? A systematic review. J. Infect. 2020, 81, e61-e66. [CrossRef] [PubMed]

294. SeyedAlinaghi, S.; Karimi, A.; MohsseniPour, M.; Barzegary, A.; Mirghaderi, S.P.; Fakhfouri, A.; Saeidi, S.; Razi, A.; Mojdeganlou, H.; Tantuoyir, M.M.; et al. The clinical outcomes of COVID-19 in HIV-positive patients: A systematic review of current evidence. Immunity, Inflamm. Dis. 2021, 9, 1160-1185. [CrossRef] [PubMed]

295. Mascolo, S.; Romanelli, A.; Carleo, M.A.; Esposito, V. Could HIV infection alter the clinical course of SARS-CoV-2 infection? When less is better. J. Med. Virol. 2020, 92, 1777-1778. [CrossRef]

296. Chen, X.P.; Cao, Y. Consideration of Highly Active Antiretroviral Therapy in the Prevention and Treatment of Severe Acute Respiratory Syndrome. Clin. Infect. Dis. 2004, 38, 1030-1032. [CrossRef]

297. Choy, K.-T.; Wong, A.Y.-L.; Kaewpreedee, P.; Sia, S.F.; Chen, D.; Hui, K.P.Y.; Chu, D.K.W.; Chan, M.C.W.; Cheung, P.P.-H.; Huang, X.; et al. Remdesivir, lopinavir, emetine, and homoharringtonine inhibit SARS-CoV-2 replication in vitro. Antiviral Res. 2020, 178, 104786. [CrossRef] 
298. Elfiky, A.A. Ribavirin, Remdesivir, Sofosbuvir, Galidesivir, and Tenofovir against SARS-CoV-2 RNA dependent RNA polymerase (RdRp): A molecular docking study. Life Sci. 2020, 253, 117592. [CrossRef]

299. Cao, B.; Wang, Y.; Wen, D.; Liu, W.; Wang, J.; Fan, G.; Ruan, L.; Song, B.; Cai, Y.; Wei, M.; et al. A Trial of Lopinavir-Ritonavir in Adults Hospitalized with Severe COVID-19. N. Engl. J. Med. 2020, 382, 1787-1799. [CrossRef] [PubMed]

300. McMichael, A.J.; Borrow, P.; Tomaras, G.D.; Goonetilleke, N.; Haynes, B.F. The immune response during acute HIV-1 infection: Clues for vaccine development. Nat. Rev. Immunol. 2010, 10, 11-23. [CrossRef]

301. Letko, M.; Marzi, A.; Munster, V. Functional assessment of cell entry and receptor usage for SARS-CoV-2 and other lineage B betacoronaviruses. Nat. Microbiol. 2020, 5, 562-569. [CrossRef]

302. Wrapp, D.; Wang, N.; Corbett, K.S.; Goldsmith, J.A.; Hsieh, C.-L.; Abiona, O.; Graham, B.S.; McLellan, J.S. Cryo-EM structure of the 2019-nCoV spike in the prefusion conformation. Science 2020, 367, 1260-1263. [CrossRef] [PubMed]

303. Walls, A.C.; Park, Y.-J.; Tortorici, M.A.; Wall, A.; McGuire, A.T.; Veesler, D. Structure, Function, and Antigenicity of the SARS-CoV-2 Spike Glycoprotein. Cell 2020, 181, 281-292.e6. [CrossRef] [PubMed]

304. Guo, L.; Ren, L.; Yang, S.; Xiao, M.; Chang, D.; Yang, F.; Dela Cruz, C.S.; Wang, Y.; Wu, C.; Xiao, Y.; et al. Profiling Early Humoral Response to Diagnose Novel Coronavirus Disease (COVID-19). Clin. Infect. Dis. 2020, 71, 778-785. [CrossRef] [PubMed]

305. Long, Q.-X.; Liu, B.-Z.; Deng, H.-J.; Wu, G.-C.; Deng, K.; Chen, Y.-K.; Liao, P.; Qiu, J.-F.; Lin, Y.; Cai, X.-F.; et al. Antibody responses to SARS-CoV-2 in patients with COVID-19. Nat. Med. 2020, 26, 845-848. [CrossRef]

306. Perera, R.A.; Mok, C.K.; Tsang, O.T.; Lv, H.; Ko, R.L.; Wu, N.C.; Yuan, M.; Leung, W.S.; Chan, J.M.; Chik, T.S.; et al. Serological assays for severe acute respiratory syndrome coronavirus 2 (SARS-CoV-2), March 2020. Eurosurveillance 2020, $25,2000421$. [CrossRef] 